NBER WORKING PAPER SERIES

\title{
SOVEREIGNS VERSUS BANKS: \\ CREDIT, CRISES, AND CONSEQUENCES
}

\author{
Òscar Jordà \\ Moritz HP. Schularick \\ Alan M. Taylor \\ Working Paper 19506 \\ http://www.nber.org/papers/w19506
}

\author{
NATIONAL BUREAU OF ECONOMIC RESEARCH \\ 1050 Massachusetts Avenue \\ Cambridge, MA 02138 \\ October 2013
}

The views expressed herein are solely the responsibility of the authors and should not be interpreted as reflecting the views of the Federal Reserve Bank of San Francisco, the Board of Governors of the Federal Reserve System, or the National Bureau of Economic Research. The authors gratefully acknowledge financial support from the Smith-Richardson Foundation. This work is part of a larger project kindly supported by a research grant from the Institute for New Economic Thinking (INET) administered by UC Davis. Schularick received financial support from the Volkswagen Foundation. For helpful comments we thank Michael Bordo, Linda Goldberg, Sebnem Kalemli-Ozcan, Romain Rancière, Carmen Reinhart, Kenneth Rogoff, and Aaron Tornell, as well those who attended presentations at the NBER Summer Institute Sovereign Debt and Financial Crises Pre-Conference, Cambridge, Mass., July 2012; the first CEPR Economic History Programme Meeting, Perugia, Italy, April 2013; the Swiss National Bank, Zurich, Switzerland, June 2013; the NBER Summer Institute DAE Meeting, Cambridge, Mass., July 2013; the Economic History Association, Arlington, September 2013; the San Francisco Fed and INET conference Finance and the Welfare of Nations, September 2013; the University of Zurich, October 2013; the Center for Latin American Monetary Studies (CEMLA), Mexico City, October 2013; the Hong Kong Monetary Authority (HKMA), the City University of Hong Kong, the Hong University of Science and Technology, the Bank of Japan, the Austrian National Bank, in November 2013; the Bank for International Settlements, the European Central Bank Financial Research Division, the Paris School of Economics Macro Seminar, the Banque de France Conference on Cross-Border Banking, and the European Commission Seminar, Brussels, in December 2013. We are particularly grateful to Early Elias and Niklas Flamang for outstanding research assistance. All errors are ours.

At least one co-author has disclosed a financial relationship of potential relevance for this research. Further information is available online at http://www.nber.org/papers/w19506.ack

NBER working papers are circulated for discussion and comment purposes. They have not been peerreviewed or been subject to the review by the NBER Board of Directors that accompanies official NBER publications.

(C) 2013 by Òscar Jordà, Moritz HP. Schularick, and Alan M. Taylor. All rights reserved. Short sections of text, not to exceed two paragraphs, may be quoted without explicit permission provided that full credit, including $\odot$ notice, is given to the source. 
Sovereigns versus Banks: Credit, Crises, and Consequences

Òscar Jordà, Moritz HP. Schularick, and Alan M. Taylor

NBER Working Paper No. 19506

October 2013, Revised February 2014

JEL No. C14,C52,E51,F32,F42,N10,N20

\begin{abstract}
Two separate narratives have emerged in the wake of the Global Financial Crisis. One interpretation speaks of private financial excess and the key role of the banking system in leveraging and deleveraging the economy. The other emphasizes the public sector balance sheet over the private and worries about the risks of lax fiscal policies. However, the two may interact in important and understudied ways. This paper examines the co-evolution of public and private sector debt in advanced countries since 1870. We find that in advanced economies significant financial stability risks have mostly come from private sector credit booms rather than from the expansion of public debt. However, we find evidence that high levels of public debt have tended to exacerbate the effects of private sector deleveraging after crises, leading to more prolonged periods of economic depression. We uncover three key facts based on our analysis of around 150 recessions and recoveries since 1870: (i) in a normal recession and recovery real GDP per capita falls by 1.5 percent and takes only 2 years to regain its previous peak, but in a financial crisis recession the drop is typically 5 percent and it takes over 5 years to regain the previous peak; (ii) the output drop is even worse and recovery even slower when the crisis is preceded by a credit boom; and (iii) the path of recovery is worse still when a credit-fueled crisis coincides with elevated public debt levels. Recent experience in the advanced economies provides a useful out-of-sample comparison, and meshes closely with these historical patterns. Fiscal space appears to be a constraint in the aftermath of a crisis, then and now.
\end{abstract}

Òscar Jordà

Economic Research, MS 1130

Federal Reserve Bank of San Francisco

101 Market St.

San Francisco, CA 94105

and University of California, Davis

oscar.jorda@sf.frb.org

Moritz HP. Schularick

Department of Economics

University of Bonn

Adenauerallee 24-42

Bonn 53113

Germany

moritz.schularick@uni-bonn.de

\author{
Alan M. Taylor \\ Department of Economics \\ University of California \\ One Shields Ave \\ Davis, CA 95616-8578 \\ and NBER \\ amtaylor@ucdavis.edu
}




\section{INTRODUCTION}

From Beijing to Madrid to Washington, the risks of excessive borrowing feature prominently in the public debate. A seemingly simple lesson that many people drew from the financial crisis is that high debts harbor risks. However, it is much less evident which debts one should worry about. A priori, many economists would probably point to the public sector where incentive failures of politicians and the common-pool problem might lead to reckless debt financing. Private households and companies, by contrast, are assumed to be acting in their enlightened self-interested, have some "skin in the game" and can be taken for "consenting adults."

Surveying such crises, or even just the latest examples, whether it was private debts that ultimately bankrupted sovereigns or excessive public debt that undermined the banking sector is a question that is not easily answered. In some Eurozone countries, the public sector was overwhelmed by the costs of cleaning up the banking system and forced to seek bail-outs (e.g., Ireland and Spain). The pattern in these cases aligns well with the link between financial crises and sovereign debt distress that has been documented in detail by Reinhart and Rogoff (2009a; 2010). In other countries, the main vulnerability was indeed concentrated on the public sector balance sheet itself (e.g., Greece). When the economic outlook worsened after the crisis, the sustainability of high public debts was called into question. Doubts about the solvency of the sovereign quickly spread to banks with substantial holdings of government debt (effects also seen in, e.g., Italy and Portugal), setting in motion a "diabolic loop" (Brunnermeier et al. 2011).

What the crisis made abundantly clear is that private and public debts cannot be looked at only in isolation. Studying the interactions between the two from a long-run historical perspective is therefore the main purpose of this paper. While various studies have looked at private and public debt separately, a joint study of the evolution of public and private borrowing is missing. With our study, we aim to start to fill this gap. To do so, we rely on a novel long-run annual panel dataset covering private bank credit and public debt and a wide swath of macroeconomic control variables for 17 advanced economies from 1870 to 2011. This is the near universe of advanced economies' experiences in the past 140 years. This long-run historical perspective allows us to work with a sufficiently large number of observations to achieve statistically meaningful results. 
We first present a number of new facts. Section 2 reveals that total economy debt levels have risen strongly over time, but the bulk of the increase has come from the private sector. Section 3 shows that private credit booms, more than public debt booms, tend to be the main precursors of financial instability. Section 4 documents the cyclical properties of private and public borrowing. Private borrowing is strongly pro-cyclical whereas public debt is usually countercyclical.

The analysis in the remainder of the paper focuses primarily on the cyclical features of Section 3 rather than the long term trends of Section 2. We track how public debt levels and private credit booms influence business cycle dynamics using local projections. We discover that both varieties of debt overhang, public and private, matter, but in different ways. The credit boom and subsequent private debt overhang primarily determine the depth of the recession and the speed of the recovery. Meanwhile, the level of public debt (rather than its buildup) influences the dynamics induced by the private debt overhang. Entering a financial crisis with high levels of public debt is associated with considerably more painful recessions and slower recoveries, potentially because high initial debt limits the fiscal space of the government.

Our results resonate with two active research areas in macroeconomics. One strand of work focuses on the role of private credit. Like Schularick and Taylor (2012), we find that financial crises often are credit booms gone bust. Crises in turn tend to have long-lasting economic effects. A number of recent studies have demonstrated that recoveries from financial crisis recessions tend to be considerably slower and more protracted than normal as private credit booms or overhangs hold back the economy.

The second strand of recent research related to our work has focused on public debt. The surge of public debt in the wake of the crisis has not only led to doubts about the efficacy of deficit spending, but also triggered fears about the negative consequences of excessive levels of public debt. Reinhart and Rogoff (2010) and Reinhart et al. (2012) argued that high public debt levels (specially beyond 90 percent of GDP) may become a drag on the economy:2 Irons and Bivens (2010) question these findings, while Minea and Parent (2012) argue that the threshold, if

\footnotetext{
${ }^{1}$ See for example Cerra and Saxena (2008); Reinhart and Rogoff (2009a); Jordà, Schularick, Taylor (2011, 2013); Mian and Sufi (2010). For different views on this question see Howard, Martin, and Wilson (2011), as well as Bordo and Haubrich (2010).

${ }^{2}$ Checherita and Rother (2010) as well as Kumar and Woo (2010) have found supporting evidence of slower growth when public debts are high.
} 
it exists, is somewhat higher at around 115 percent of GDP. In a related part of the literature, Corsetti et al. (2012) argue that if risk premia on public debt rise with higher levels of public debt, the multiplier effects of fiscal policy shrink. Ilzetzki et al. (2013) find a similar result for emerging economies.

The key findings of this paper provide nuanced support for both strands of this literature. On the one hand, we reaffirm the central role played by private sector borrowing behavior for the build-up of financial fragility. In advanced economies, the idea that financial crises typically have their roots in fiscal problems which in turn take a toll on the banking sector is not supported by history as a general matter. Emerging economies might be different in this respect. On the other hand, our results also speak to the potential dangers of high public debt in some situations. While high levels of public debt make little difference in normal times,

entering a financial crisis recession with an elevated level of public debt seems to exacerbate the effects of private sector deleveraging and is typically accompanied by a prolonged period of sub-par economic performance. That is, the long-run data suggest that without enough fiscal space, a country's capacity to perform macroeconomic stabilization and resume growth after a major crisis downturn may be seriously impaired.

\section{The Historical Evolution of Public Debt and Private CREDIT SINCE 1870}

The experience of the Euro Area periphery during the recent Global Financial Crisis exemplifies the connection that exists between private credit growth and financial crises on the one hand, and public debt and sovereign crises on the other. In 2007, Spain had a budget surplus of about 2 percent of GDP and its general government debt stood below 40 percent of GDP 3 By 2012, Spain's government debt had doubled to reach about 90 percent of GDP. What began as a banking crisis driven by the collapse of the real estate bubble, quickly turned into a sovereign debt crisis. A similar, possibly even more dramatic, story could be told for Ireland. The lesson of these episodes seems to be that there was next to nothing in key indicators of public finances that indicated the imminent catastrophe. The build-up of financial risks mainly occurred on private balance

\footnotetext{
3Source: OECD, Country Statistical Profile.
} 
sheets. In other words, public and private sector debt cannot be looked at in isolation. Yet the debate about mounting public debt levels in advanced economies has often focused on a narrower view of the historical experience, paying little attention to the development of private credit.

This section provides an overview of the co-evolution of private and public sector debt over the last 140 years. The data deployed in this paper are an update of the dataset compiled in Schularick and Taylor (2012) with more recent observations, more countries (now including the experiences of Belgium, Finland and Portugal), and more variables (including data on the fiscal positions and public debt of individual countries). It is important to note that the new dataset builds on the research efforts of many economic historians in various countries and brings data from various sources together in one place. Without the generous support from colleagues around the world we would not have been able to compile this novel source for macrohistorical research. In particular, the sample includes observations from 1870 to 2011 at annual frequency for 17 advanced economies representing over $50 \%$ of world output (and close to $100 \%$ of advanced economy output) more or less consistently throughout the sample period (Maddison 2005).

Our dataset builds on updated series for bank loans to the non-financial domestic private sector collected from historical sources such as banking supervisory statistics or national statistical yearbooks. In the subsequent analysis, we will use this information about the asset side of banks' balance sheets as a proxy for total private sector debt growth. The main reason for using this proxy is data availability. There are no reliable cross-country historical data for the size of corporate bond markets or the lending activities of non-bank financial intermediaries. Some evidence exists to suggest that a substantial share of private debt was held privately in the 19th century. Although precise numbers are hard to come by, both in France and the U.K. privately held mortgage debt accounted for up to 1o percent of GDP around the year 1900; in the U.S. and Germany, an even higher share of farm and non-farm mortgages was likely held outside financial institutions (Hoffman, Postel-Vinay, and Rosenthal 200o). In some countries, corporate bond markets were sizeable too and played an important role in providing finance for railroad construction and other overhead investment. Yet, despite the importance of these other forms of financing, bank credit typically accounts for a large and often predominant form of private sector borrowing in industrial countries.

Using the comparative national balance sheets calculated by Goldsmith (1985) 
we can approximate the share of bank credit in total private sector liabilities over time. The data from Goldsmith sometimes rely on bold assumptions and are clearly not free of problems, but they allow us to check the broad trends. Goldsmith's data show that in 1913 borrowing from banks accounted for about half of total private debt in many countries. Comparing our bank credit data to the total financial liabilities given by Goldsmith for the year 1913 yields ratios of around 50 percent for Belgium and the U.S., and closer to 60 percent for Germany and the U.K., depending on assumptions about the share of mortgages held outside the banking system. In 1930 bank credit equally accounted for 50-60 percent of total private sector debt both in the U.S. and the U.K., again based on Goldsmith's (1985) national balance sheet data. The comparison becomes easier after 1945 as flow of funds data in some cases provide alternative information on total private sector debt which we can compare directly to our series for bank lending. In the U.S. bank credit accounted for 53 percent of private sector debt in 1960 and close to 60 percent in 1970 and 55 percent in 1980, but has been falling since then to about 40 percent in 2000.

Summing up, the share of private sector debt not covered by our database is likely to have been larger in the years before World War I and in the past two decades of rapid growth of lending by non-bank intermediaries, but accounted for a substantial and often dominant share of private sector debt throughout the past 140 years. Moreover, bank and non-bank debt growth rates tended to correlate closely in the years for which we have detailed data on both.

Figure 1 displays the private-credit-to-GDP and public-debt-to-GDP ratio ratio for the 17 countries in the sample, using as metrics our bank lending measure and general government debt. Several features deserve comment. On the public debt side, the dominant event in the zoth century is clearly World War II. The war raised the level of public debt to unprecedented levels, often breaching the 1oo percent debt to GDP level (and in the case of Germany, Japan, and the U.K. shooting past 200 percent). In the reconstruction boom of the Bretton Woods era, public debt levels gradually declined over the thirty years following the end of the war, reaching a nadir of about 30-40 percent debt to GDP around the mid-1970s. Since the late 1970s, public debt levels steadily increased until the mid-1990s before improving somewhat in the decade before the crisis. The Global Financial Crisis put an end to this gradual improvement. Fiscal balances have worsened considerably and public debt has now shot up to levels last seen in World War II. 
Figure 1: Public debt and private bank credit to the private non-financial sector, 1870-2011

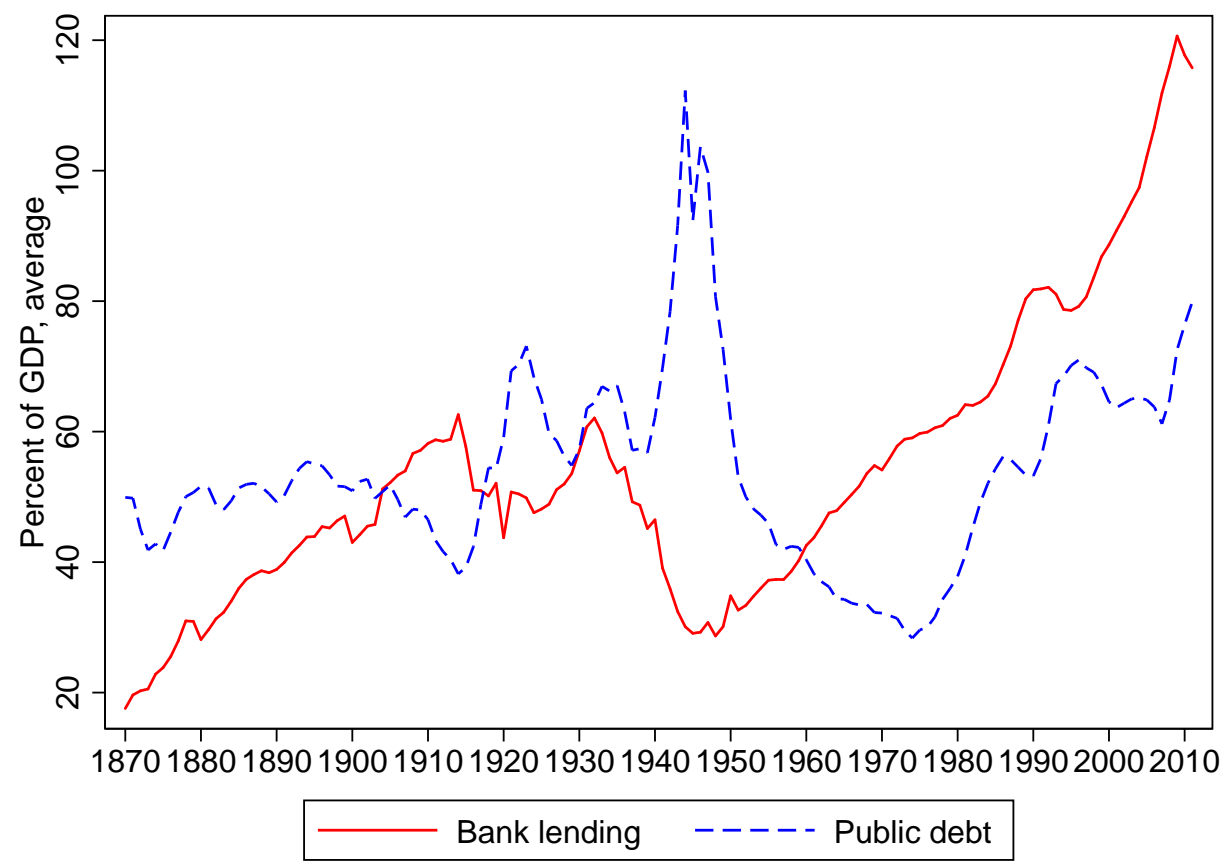

Notes: The sample period is $1870-2011$ and the annual averages are shown for 17 advanced countries. Total private credit is proxied by total bank loans to the nonfinancial sector, excluding interbank lending and foreign currency lending based on Schularick and Taylor (2012) and updates thereto. Public debt is the face value of total general government debt outstanding.

However, these broad trends in public finance should be set against the startling trends in private credit discussed by Schularick and Taylor (2012). Leading up to World War II bank credit to the non-financial sector maintained a fairly stable relationship with GDP. The median of bank lending to GDP was in the 40-50 percent range for most of the pre-World War II period. Private credit collapsed in the Depression and during World War II when public debt expanded rapidly. Bank credit recovered its prewar levels by the 1970s and surged to unprecedented levels in the following decades, well over 100 percent of GDP in our sample. (Bearing in mind our earlier discussion of bank versus total private credit, using Goldsmith's fragmentary data above, the levels of total private credit are probably around twice these levels.) The implications of this financialization of Western economies are profound and have become an active area of investigation.

Visualizing the development of the two kinds of debts (private and public) in our sample, Figure 2 shows the size of the banking sector (proxied by total bank 
lending) and public debt for three different years separated by roughly 40 year intervals covering our sample. The top panel corresponds to 1928, the year before the Great Depression began in most countries. The middle panel corresponds to 1967, just before the rapid climb in private and public debt discussed earlier and visible in Figure 1 . The bottom panel corresponds to 2007, the year before the start of the recent Global Financial Crisis. Here bank assets includes loans to the non-financial sector, plus interbank lending and bank holdings of securities.

This exercise yields some interesting insights. First, the average level of public debt to GDP in 1928 was about 60 percent, virtually identical to the average level in 2007. Put differently, there has been very little change in public debt levels from the 1920 s until to the start of the Global Financial Crisis. Second, the average level of bank lending to GDP in 2007 has doubled relative to the level seen in 1928, and seen again in 1967. At those earlier dates few advanced countries had bank lending over $90 \%$ of GDP; by 2007 most of them did. Almost all of the increase in total (public and private) debt in the course of the 2oth century was due to an expansion of bank lending. Averaging across all 17 advanced countries, the ratio of public debt to bank lending went from roughly 1:1 in 1928, to 1:1.5 in 1967, and to $1: 2$ in 2007. Third, while public debts have increased in most, albeit not all, Western economies in the late twentieth century, public debt has only risen half as fast as bank lending since the 1970 .

Summing up, aggregate debt (the sum of public debt and private credit) has grown to historically unprecedented levels in Western economies over the last century and a half. The break with the past is particularly evident since the 1970s. However, the increase in economy-wide debt levels has been dominated by the behavior of the private sector (bank lending) and not by the public sector: it is private sector borrowing from banks, not public sector debt, that reached historically unprecedented levels in Western economies in the early zooos on the eve of the recent crisis.

\section{Sources of Financial Instability: Sovereigns versus Banks}

Is private or public borrowing the greater risk to financial stability? Historical evidence suggests that private sector credit booms often end in crises. The 2008 crisis clearly followed this historical pattern. In the U.K., Denmark, and Spain credit to the private sector expanded by 70 percentage points (pps) to GDP in 
Figure 2: Relative sizes of private and public balance sheet sizes across countries and over time: Three snapshots of public debt and bank lending for 1928, 1967, and 2007

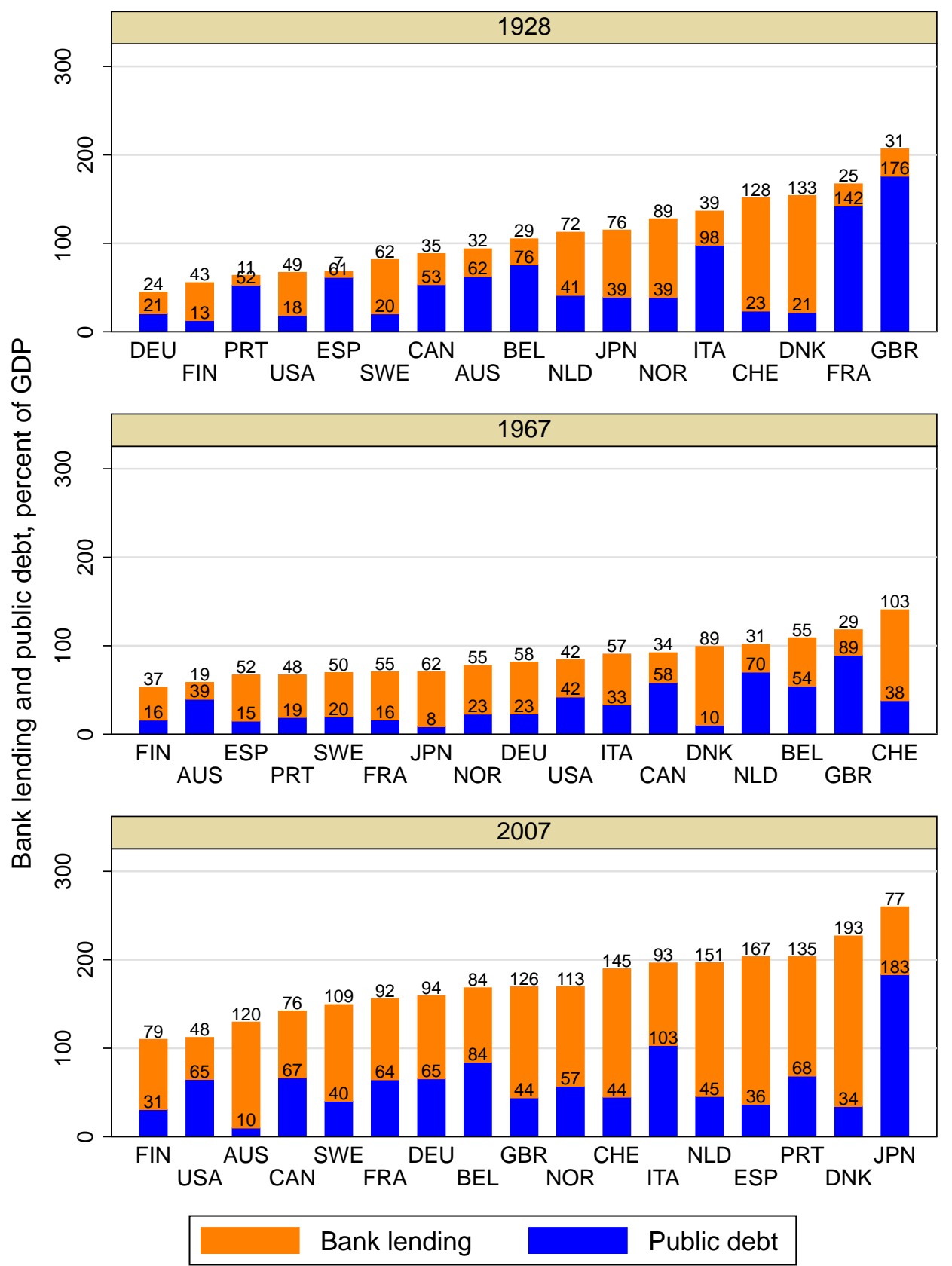

Notes: For each country, the bottom bar reflects the level of public debt to GDP. The top bar reflects the level of bank lending to GDP. Countries arranged by the size of the sum of public debt and bank lending to GDP at each date. For 1967, the Switzerland observation uses data for 1965, the closest available year. 
the five years preceding the global financial crisis; in Ireland the credit to GDP ratio rose by even more at over 100 pps. In the U.S. the increase was a still sizable 50 pps between 2002 and 2007. With the benefit of hindsight, the recent events evidently followed in the footsteps of previous lending booms. The Scandinavian and Japanese financial crises in the 1980 and 1990s also followed a period of rapid credit expansion. More than a decade ago, Eichengreen and Mitchener (2003) called the Great Depression a "credit boom gone wrong." In our long-run dataset, three quarters of all episodes during which credit to GDP rose by more than 30 pps (or more) over a five-year period ended in a systemic crisis.

Clearly, not all financial crises fit this classification. Crises have also been caused by exogenous events such as the effect of weather on agricultural production and prices, changes in the terms of trade, or sudden stops in capital flows. Especially in the 19th century, with the absence of a lender of last resort, such shocks could quickly lead to banking panics and financial crises. The U.S. experience in particular was marked by railroad construction booms and busts, often in tune with the ebbs and flows of foreign capital inflows, and the vagaries of farm crop prices and production.

Yet also in the pre-World War I era, credit booms and periods of easy lending often preceded financial crises. For instance, the 1893 depression was foreshadowed by strong growth in non-farm and farm mortgage lending. In the decade before the 1893 crisis, loans extended by American banks roughly doubled relative to GDP. Easy global credit fueled a multi-year construction boom in the 1880s, in places as far afield as Argentina and Australia, that ended when international capital inflows reversed in the wake of the Baring crisis of 1891. In Germany, the Gruenderkrach in 1873 and the ensuing Gruenderkrise as well as the 1907 crisis also followed periods of sharp accelerations of credit growth relative to the previous decades (Tilly 2003). In the 10 years preceding the 1907 financial crisis, the credit to GDP ratio rose by more than 20 pps. relative to GDP in Germany and by 30 pps. in neighboring Denmark.

To study the role of private and public sector debt in generating financial instability, this section builds on the classification framework developed in Jordà and Taylor (2011) and Schularick and Taylor (2012) using our expanded long-run 17 country dataset. We start from a probabilistic model that specifies the log-odds ratio of a financial crisis event occurring in country $i$, in year $t$, as a linear function of lagged controls $X$, including changes in the private credit and public debt to 
GDP ratios and their levels,

$$
\log \frac{P\left[S_{i t}=1 \mid X_{i t}\right]}{P\left[S_{i t}=0 \mid X_{i t}\right]}=b_{0 i}+b_{1}(L) X_{i t}+e_{i t},
$$

where $L$ is the lag operator and the model allows for country fixed-effects.

Given the predicted odds from this model, denoted $\hat{p}$, we then evaluate whether a classifier or assignment rule, $I(\hat{p}>c)$, can do better than the null (a coin toss) in sorting the binary crisis event data given the threshold $c$. To proceed with formal inference, we use the techniques discussed by Jordà and Taylor (2011). We chart all combinations of true positives against true negatives in the unit box by varying the threshold $c$ between $-\infty$ and $+\infty$, and create a Correct Classification Frontier (CCF). A classifier is informative if its CCF is above the null CFF of a coin toss, which lies on the diagonal. Formally, we can test if the area under the curve (AUC) exceeds 0.5 for the null to be rejected, and inference on families of AUCs turns out to be simple as their asymptotic distributions are normal.

In specifying the log-odds ratio in expression (1), we allow the controls to enter as 5-year moving averages. This is a parsimonious way to summarize mediumterm fluctuations and to facilitate the investigation of the interaction between public debt and private credit movements. We report estimates based on a variety of specifications detailed below. The error term $e_{i t}$ is assumed to be well behaved, and wartime years are omitted from the estimation as in our previous work.

Dates of systemic financial crises are based on an update to the study by Jordà, Schularick, and Taylor (2013), which built on the timing of crisis events pioneered by Bordo et al. (2001) and Reinhart and Rogoff (2009b) for historical times. The Laeven and Valencia $(2008,2012)$ dataset of systemic banking crises is the main source for post-1970 crisis events. Following the definition of Laeven and Valencia (2012), a financial crisis is characterized as a situation in which there are significant signs of financial distress and losses in wide parts of the financial system that lead to widespread insolvencies or significant policy interventions 4 Since 1870, there have been no less than 94 systemic financial crises in the sample of 17 countries

\footnotetext{
4The important distinction here is between isolated bank failures, such as the collapse of the Herstatt Bank in Germany in 1975 or the demise of Baring Brothers in the U.K. in 1995, and system-wide distress as it occurred, for instance, in the crises of the 1890s and the 1930s, in the Japanese banking crises in the 1990s, or during the Global Financial Crisis of 2008. It is clear that the lines are not always easy to draw, but the overall results appear robust to variations in the crisis definitions.
} 
Table 1: Financial crisis classification ability: private credit versus public debt

The table shows logit model classifiers where the dependent variable is the financial crisis event dummy, and the regressors are lags and/or levels of private credit/GDP and public debt/GDP, their interaction, and country fixed effects.

\begin{tabular}{|c|c|c|c|c|c|}
\hline Classifier logit model & (1) & (2) & (3) & (4) & (5) \\
\hline $\begin{array}{l}\text { Change in private credit/GDP } \\
\text { (5-year moving average) }\end{array}$ & $\begin{array}{c}21.79^{* * *} \\
(5 \cdot 39)\end{array}$ & & $\begin{array}{c}21.34^{* * *} \\
(5.44)\end{array}$ & $\begin{array}{l}26.63^{* *} \\
(13.00)\end{array}$ & \\
\hline $\begin{array}{l}\text { Change in public debt/GDP } \\
\text { (5-year moving average) }\end{array}$ & & $\begin{array}{l}-2.83 \\
(1.88)\end{array}$ & $\begin{array}{l}-3.17 \\
(3.68)\end{array}$ & & $\begin{array}{l}-4.21 \\
(3.29)\end{array}$ \\
\hline Lagged level of private credit/GDP & & & & $\begin{array}{l}-0.03 \\
(0.63)\end{array}$ & \\
\hline Lagged level of public debt/GDP & & & & & $\begin{array}{l}-0.03 \\
(0.29)\end{array}$ \\
\hline $\begin{array}{l}\text { (Lagged level of private credit/GDP) } \\
\times(\text { Lagged level of public debt/GDP) }\end{array}$ & & & & $\begin{array}{l}-3.63 \\
(9.34)\end{array}$ & $\begin{array}{c}0.45 \\
(3.02)\end{array}$ \\
\hline Observations & 1901 & 1983 & 1805 & 1895 & 1850 \\
\hline Area under the curve (AUC) & $\begin{array}{c}0.68 \\
(0.03)\end{array}$ & $\begin{array}{c}0.61 \\
(0.03)\end{array}$ & $\begin{array}{c}0.68 \\
(0.03)\end{array}$ & $\begin{array}{c}0.68 \\
(0.03)\end{array}$ & $\begin{array}{c}0.61 \\
(0.03)\end{array}$ \\
\hline
\end{tabular}

Notes: ${ }^{* * *} \mathrm{p}<0.01,{ }^{* *} \mathrm{p}<0.05,{ }^{*} \mathrm{p}<0.1$. Robust standard errors in parentheses. Country fixed effects not shown. The reference null model based on a specification with country fixed effects only has an AUC $=0.59$ (0.03). The two world wars are excluded from the estimation sample.

used here. A complete list of systemic financial crises for our dataset can be found in the data appendix.

The key results are shown in Table 1 based on 17 advanced countries for the period 1870 to 2011. Starting with the simple model based on credit used in Schularick and Taylor (2012, Table 3), we run rival models with public debt added as an alternative, or in combination with the private credit measure. The question is, do any of these alternative variables add any information at all?

The answer seems to be no. In columns (1) and (2), the AUC of the private credit model for the full sample is 0.68 with a standard error of 0.03 . The AUC of the public debt model is 0.61 with a standard error of 0.03 , which is virtually identical to (and not significantly different from) the AUC of 0.59 for the null reference model with only country fixed effects. The joint model has an AUC that is virtually identical to the pure private sector credit model indicating that little is gained by including public debt information in the long-run. We also checked 
the robustness of these results by including additional controls for the level of credit and debt or an interaction between the two, but none of these specifications affected our key results and the additional controls were not statistically significant, as the table shows.

In addition, we ran a number of robustness checks. We included GDP growth relative to trend as a control to see if crises are more likely in times of slow growth. We also split the sample to examine whether crisis dynamics differ between pre and post-World War II. The results remained unaffected by the sample splitcredit remains a statistically significant indicator for financial instability in both periods. In addition, growth trends turn out not to correlate closely with financial fragility before World War II. The link is somewhat tighter after World War II, but fails to be significant at standard thresholds.

Summing up, the idea that financial crises have their roots in fiscal problems finds little support over the long sweep of history. Some cases may of course exist-like Greece today - but these cases have been the exception not the rule. In general, like Ireland and Spain today, financial crises can be traced back to developments in the financial sector itself.

\section{Private Credit and Public Debt over the Business Cycle, 1870-2011}

One explanation for the results of the previous section could be differences in the cyclicality of private credit and private debt. How do private credit and public

borrowing evolve over the business cycle? Are they procyclical or countercyclical? Have the dynamics of private credit and public debt changed in different eras and under different monetary regimes? And how does the behavior of private credit and public debt differ between normal cycles and those associated with financial crises? These are the questions we address in this section.

\subsection{Methods}

There are no official data on business cycle turning points going back 140 years and covering all the countries in our sample. We investigate the business cycle features of the data by generating two auxiliary dummy variables using the intuition in the Bry and Boschan (1971) algorithm. At a yearly frequency this 
algorithm replicates the NBER's dating of U.S. business cycle peaks and troughs almost perfectly.

The algorithm generates dates of peaks and troughs in economic activity for each country in our sample separately. Conveniently, this simple algorithm does not require any prior detrending of the data. Using real GDP per capita, a peak corresponds to a local maximum whereas a trough corresponds to a local minimum. Therefore, recessions refer to the period between a peak and the following trough, whereas expansions refer to the period between the trough and the subsequent peak. By definition, peaks and troughs perfectly alternate one another.

Using these peaks and troughs we can compute three cyclical statistics of interest for any given variable: amplitude, duration and rate. Amplitude denotes the average change between turning points; duration refers to the average interval of time elapsed between turning points; and rate is simply the ratio of amplitude over duration and provides a per year rate of change.

\subsection{Five Stylized Facts}

Using this dating method, we can sketch the broad contours of output, debt, and credit in the modern business cycle. Remember that our sample of 17 economies represents the near-universe of advanced economies for which long-run data exist. The following five facts about the modern business cycle and encapsulated in Figure 3 stand out.

First, as panel (a) shows, the typical expansion has become longer lasting. Expansions lasted less than 3 years before World War I, almost 4 years between the two world wars, 6 years during the Bretton-Woods era, and 10 years since. As expansions have become longer-lasting output per capita amplitudes in expansions have gradually risen as well. It is striking that recessions have lasted I year on average in all periods, but were deeper during the interwar era.

Second, the annual rate of real GDP growth in the expansion (amplitude divided by duration) has gradually declined. It averaged 3.5 percent per annum (p.p.a.) before World War I, peaked at 5.2 p.p.a. in the interwar period, declined to 4.3 p.p.a. in the Bretton Woods era, and currently averages about 2.7 p.p.a. In other words, business cycles last longer but annual growth rates have come down.

Third, private bank lending is distinctly pro-cyclical. It grows faster in expansions than in recessions, and increasingly so. In a typical cycle of the post 
Figure 3: Real GDP, Private Credit, and Public Debt Over the Business Cycle

(a) Real GDP Over the Business Cycle: Amplitude, Duration and Rate Real GDP per capita
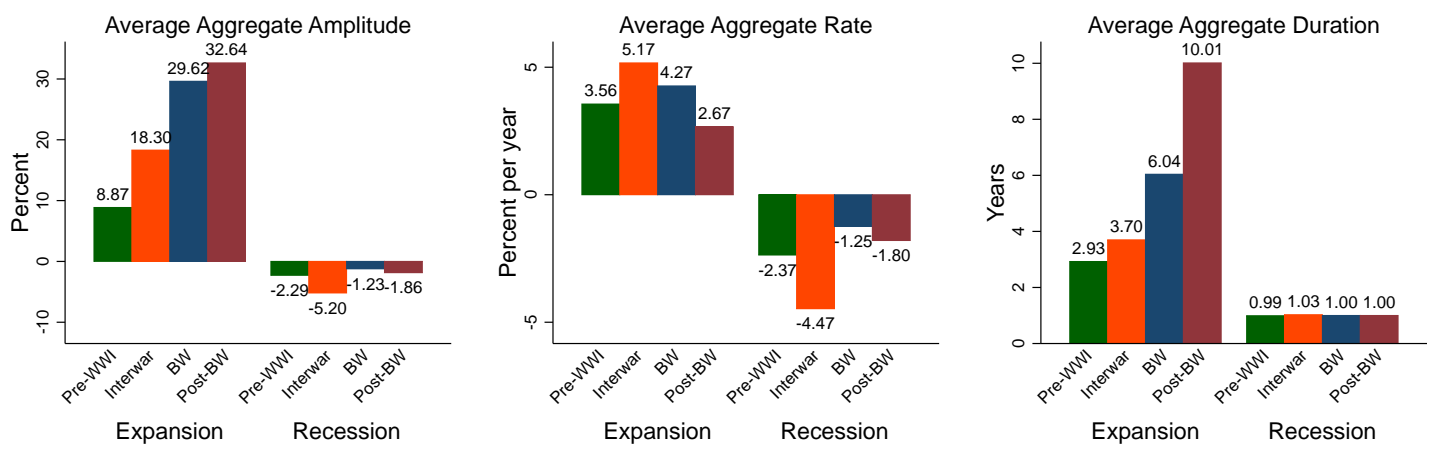

(b) Private and Public Debt Over the Business Cycle: Amplitude and Rate

\section{Real lending per capita}
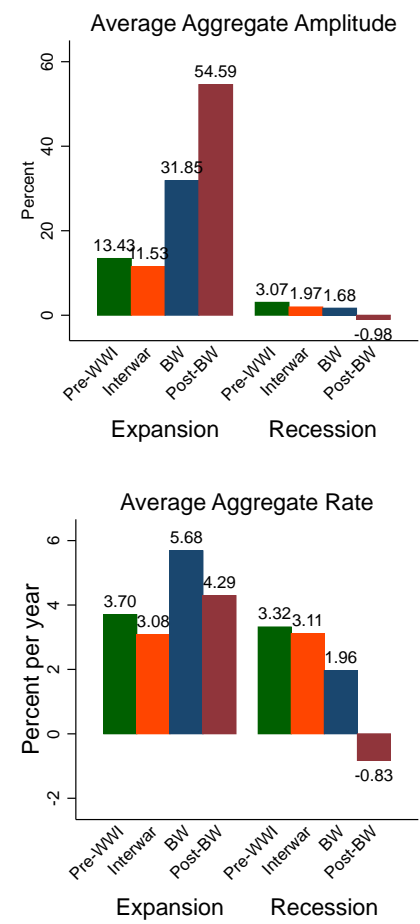

Real public debt per capita
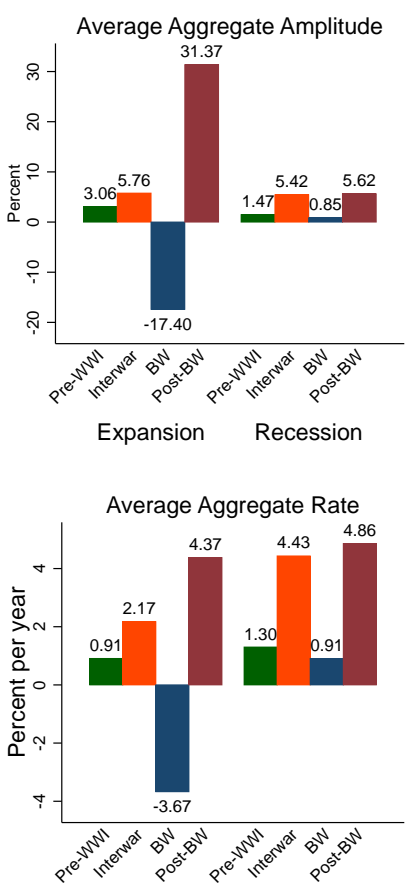

Expansion Recession
Real combined leverage per capita
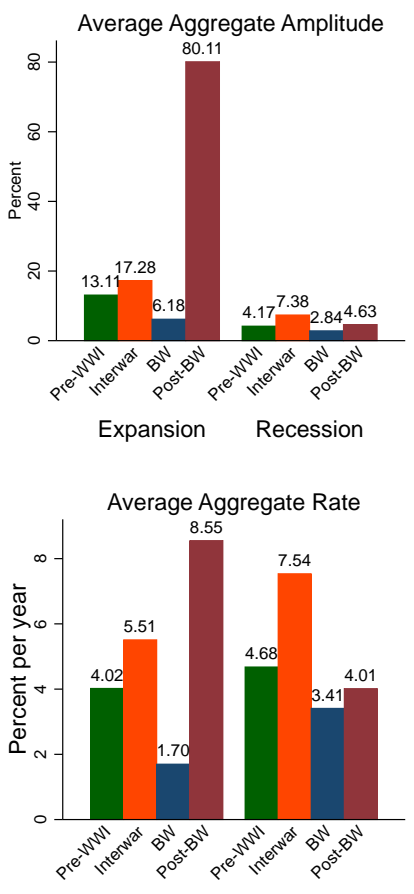

Expansion Recession

Notes: Amplitude, duration, and rate are as defined in the text: duration is the length from start to end of the expansion/recession phase for real GDP per capita, in years; amplitude is change in any variable over the phase, in percent; rate is amplitude of any variable divided by the duration over the phase, in percent per year. BW denotes the Bretton Woods period. 
Bretton Woods era real private credit per capita increased by about 55 percent, about double the growth rate of per capita GDP (see Figure 3 (b), column 1).

Fourth, public debt tends to grow faster in recessions than in expansions, indicating there is some counter cyclical stance to pubic borrowing. Moreover, the Bretton-Woods period stands out as the only period where public debt was reduced in both expansions and recessions (Figure 3(b), column 2). In the immediate postwar decades countries gradually reduced their World War II debt obligations aided by the reconstruction boom and tight financial system control.

Fifth, the combined sum of public debt and private credit (Figure 3(b), column 3) has grown at an unprecedented pace in the past four decades. It is evident from the chart that the 1970s mark a major break in the dynamics of aggregate debt. The combination of strong private credit growth and higher public borrowing put the annual growth of total liabilities at 8.5 p.p.a. in expansions and 4.0 p.p.a in recessions, a remarkable development in the history of the last 140 years.

In sum, we find that business cycles have gradually become longer lasting and much more credit-intensive. Private borrowing tends to be strongly pro-cyclical while public borrowing displays some counter cyclical elements in advanced economies. In modern economic history, the Bretton-Woods period stands out as the only period of sustained public debt reduction, both in expansions and recessions.

\subsection{Booms, Busts, and Crises}

Not all cycles are created equal. Some cycles end in financial crises and severe recessions, while others do not. The natural next step is to ask how the cyclical behavior of credit differs between normal cycles and those that end in severe financial crises.

We therefore introduce a distinction between recessions that coincide with a major financial crisis - we call these financial crisis recessions - and those without major financial disruptions normal recessions. More precisely, we call a recession financial if a major financial crisis erupts within a two year window around the peak (the start of the recession). This classification is summarized in a data appendix table and extends prior work in Jordà, Schularick, and Taylor (2013) with added data for Belgium, Finland and Portugal and the post-2008 years, and some refinements to the definitions of financial crisis dates. 
Table 2 summarizes the universe of recessions and their classification using this approach. The table is broken into three panels. Panel (a) corresponds to the full sample, panel (b) to the pre-World War II sample, and panel (c) to the post-World War II sample. The full sample contains 269 recession episodes of which 63 are classified as financial crisis recessions and 206 are classified as normal recessions. The proportion varies with each sub-sample. In the pre-World War II era 1 in 3 recessions was a financial crisis whereas after World War II the proportion decreases to about 1 in 5 .

The table also includes information on changes in private credit, public debt ratios, and public debt levels measured respectively as the percentage point change per annum in private credit and public debt over GDP, and as a fraction of GDP, each measured over the business cycle expansion. With respect to private credit, the key result arising from the table is that private credit grows twice as rapidly before financial crisis recessions than before normal recessions, regardless of the era. From a business cycle perspective, this clearly reinforces the earlier finding that financial crises tend to be preceded by a rapid accumulation of private liabilities.

The public debt to GDP ratio, by contrast, tends to decline before normal and financial crisis recessions. In the pre-World War II sample, public debt declines at a rate of about 1 p.p.a. before normal recessions and o.3 p.p.a. before financial crisis recessions. After World War II the difference between normal and financial cycles is starker. Whereas debt declines by a similar amount in normal recessions, about 0.9 p.p.a, it increases at a rate of about 0.4 p.p.a. before financial crisis recessions. However, this result is driven by the absence of financial crises under the Bretton Woods System and the parallel reduction in public debt in the postwar reconstruction boom. In fact, looking at debt levels as a fraction of GDP there are hardly any difference across eras or across the type of recession.

Summing up, we find that business cycles associated with financial crises tend to exhibit much more credit-intensive expansions. Across all countries and periods, public debt tends to decline in expansions that end in financial crises, but these declines are small. The lesson seems to be that, at least in advanced economies, the build-up of financial fragility typically occurs on private sector balance sheets, not through the government's budget. 
Table 2: Summary statistics for recessions, private credit, and public debt variables

Financial crisis and normal recession indicators are binary 0-1. Changes in private credit and public debt are in percentage points change per year in the prior expansion. Public debt level is the ratio relative to GDP at the business cycle peak.

\begin{tabular}{|c|c|c|c|c|c|c|}
\hline \multirow{3}{*}{$\begin{array}{l}\text { (a) Full sample } \\
\text { Financial recession indicator } \\
\text { Observations }\end{array}$} & \multicolumn{2}{|c|}{$\begin{array}{c}\text { All } \\
\text { Recessions }\end{array}$} & \multicolumn{2}{|c|}{$\begin{array}{c}\text { Financial } \\
\text { Recessions }\end{array}$} & \multicolumn{2}{|c|}{$\begin{array}{c}\text { Normal } \\
\text { Recessions }\end{array}$} \\
\hline & 0.23 & & 1.00 & & 0.00 & \\
\hline & 269 & & 63 & & 206 & \\
\hline Normal recession indicator & 0.77 & & 0.00 & & 1.00 & \\
\hline Observations & 269 & & 63 & & 206 & \\
\hline Change in private credit/GDP & 0.70 & $(2.26)$ & 1.73 & $(2.35)$ & 0.41 & $(2.15)$ \\
\hline Observations & 198 & & 44 & & 154 & \\
\hline Change in public debt/GDP & -0.76 & $(6.06)$ & -0.13 & $(3.65)$ & -0.95 & $(6.62)$ \\
\hline Observations & 218 & & 51 & & 167 & \\
\hline Public debt level/GDP & 0.51 & $(0.36)$ & 0.50 & $(0.34)$ & 0.51 & $(0.37)$ \\
\hline Observations & 247 & & 58 & & 189 & \\
\hline (b) Pre-World War II sample & Rece & ions & $\begin{array}{l}\text { Fin } \\
\text { Rec }\end{array}$ & $\begin{array}{l}\text { cial } \\
\text { ions }\end{array}$ & $\begin{array}{r}\mathrm{Nc} \\
\mathrm{Rec}\end{array}$ & $\begin{array}{l}\text { nal } \\
\text { ions }\end{array}$ \\
\hline Financial recession indicator & 0.28 & & 1.00 & & 0.00 & \\
\hline Observations & 186 & & 52 & & 134 & \\
\hline Normal recession indicator & 0.72 & & 0.00 & & 1.00 & \\
\hline Observations & 186 & & 52 & & 134 & \\
\hline Change in private credit/GDP & 0.54 & $(2.38)$ & 1.35 & $(2.17)$ & 0.25 & $(2.40)$ \\
\hline Observations & 124 & & 33 & & 91 & \\
\hline Change in public debt/GDP & -0.81 & $(6.75)$ & -0.28 & $(3.89)$ & -1.01 & $(7 \cdot 54)$ \\
\hline Observations & 149 & & 40 & & 109 & \\
\hline Public debt level/GDP & 0.52 & $(0.37)$ & 0.51 & $(0.35)$ & 0.52 & $(0.38)$ \\
\hline Observations & 167 & & 47 & & 120 & \\
\hline (c) Post-World War II sample & Rece & ions & $\begin{array}{l}\text { Fin } \\
\text { Rec }\end{array}$ & $\begin{array}{l}\text { cial } \\
\text { ions }\end{array}$ & $\begin{array}{r}\mathrm{No} \\
\text { Rece }\end{array}$ & $\begin{array}{l}\text { nal } \\
\text { ions }\end{array}$ \\
\hline Financial recession indicator & 0.13 & & 1.00 & & 0.00 & \\
\hline Observations & 83 & & 11 & & 72 & \\
\hline Normal recession indicator & 0.87 & & 0.00 & & 1.00 & \\
\hline Observations & 83 & & 11 & & 72 & \\
\hline Change in private credit/GDP & 0.97 & $(2.03)$ & 2.90 & $(2.58)$ & 0.64 & $(1.73)$ \\
\hline Observations & 74 & & 11 & & 63 & \\
\hline Change in public debt/GDP & -0.65 & $(4.26)$ & 0.40 & $(2.65)$ & -0.85 & $(4 \cdot 49)$ \\
\hline Observations & 69 & & 11 & & 58 & \\
\hline Public debt level/GDP & 0.48 & $(0.34)$ & 0.48 & $(0.33)$ & 0.48 & $(0.34)$ \\
\hline Observations & 80 & & 11 & & 69 & \\
\hline
\end{tabular}

Notes: The mean is shown. For nonbinary variables the standard deviation is in parentheses. 


\section{Debt Booms and Overhangs: Private and Public}

What does the long-run historical evidence say about the prevalence and effects of private and public debt booms and overhangs? Do high levels of public debt affect business cycle dynamics, as the public debt overhang literature argues? Are the effects of either variety of debt overhang more pronounced after financial crisis recessions? These are the questions that we explore in the next few sections. First, some background on the existing tensions in the literature.

The empirical observation that recoveries from financial crisis recessions seem to be special (see e.g. Cerra and Saxena, 2008; Reinhart and Rogoff 2009a; and Claessens, Kose and Terrones, 2011) has prompted researchers to look deeper into the causes of slow recoveries. One key theme is that high and/or newly-elevated levels of private indebtedness-a "debt overhang" - may hold back economic recovery after financial crises. In the crisis, agents in the economy suddenly realize that asset values were too high and leverage limits too lax. After this "Minsky moment" households (or companies) repair their balance sheets and adjust their debt levels. This deleveraging process in turn may weigh on aggregate demand and be responsible for the sluggish recovery (Koo 2008; Mian, Rao, Sufi 2011; Mian and Sufi 2010).

Krugman and Eggertsson (2012) present a model with heterogeneous households: some households are patient creditors, others are impatient debtors. When credit conditions tighten in a crisis, indebted households have to cut back on consumption to adjust to the new borrowing constraint. The real interest rate needs to fall to induce higher spending by patient households, but the zero lower bound may prevent full adjustment in the short run. Hall (2011), Guerrieri and Lorenzoni (2011), as well as Philippon and Midrigan (2011), develop similar ideas. Jordà, Schularick and Taylor $(2011,2013)$ demonstrate in related empirical work that private debt overhang effects after credit booms are a regular feature of the business cycle.

Another strand of the literature warns of the effects of the overhang from public, not private, borrowing. Reinhart et al. (2012) studied 26 episodes where public debt to GDP accounted for more than 90 percent of GDP on a sustained basis and found evidence that these public debt overhang episodes were associated with a substantial slowdown of GDP growth relative to low-debt years. These results echoed those of a much-debated earlier contribution by Reinhart and 
Rogoff (2010) that presented evidence that above a certain public debt to GDP threshold the overhang of public debt goes hand in hand with a substantial slowdown in economic growth.

The empirical approach that we follow to address these issues is multifaceted. After a short presentation of our key statistical methods (section 5.1), we will revisit the historical evidence on private credit booms (section 5.2). More precisely, we study if and how private credit booms influence the depth of recession and the speed of the recovery. We find that private credit build-up during the expansion tends to make the recession deeper and longer lasting, confirming and thus extending the results in Jordà, Schularick, and Taylor (2011, 2013).

In the next step (section 5.3), we take a closer look at the effects of public debt booms. Importantly, we improve upon previous studies of public debt boom episodes by moving beyond a simple unconditional analysis and including a number of additional macroeconomic controls that could account for the muchdebated low growth correlation seen during times of high public indebtedness.

Lastly (section 5.4), we look at the interaction between private credit buildups and the level of public debt. We find that high levels of public debt exacerbate the effects of private sector deleveraging. The combination of private sector credit booms with high levels of public sector debt typically leads to considerably deeper recessions and slower recoveries. Our results therefore lend support to precautionary fiscal policy regimes to keep public sector debt low during normal times-not because these debts necessarily endanger growth, but for a more narrow, specific reason: to avoid the need for a parallel retrenchment of private and public sector borrowing in times of crisis, and in the associated and typically prolonged recession which follows.

\subsection{Statistical Design}

The statistical toolkit we use relies on the local projection (LP) approach introduced in Jordà (2005). Several reasons justify this choice.

The sample of data available may appear abundant for most statistical analyses. However, we are interested in characterizing a number of dynamic multipliers from a multivariate perspective. Standard models are far too parametrically intensive for the available sample. Moreover, some of the multipliers that we calculate allow for asymmetries and nonlinearities in the form of modulation 
via the level of debt at the start of the recession. These features are difficult to model with assumptions about the underlying global data generating process. And in any case, this would impose numerical burdens that our sample cannot easily bear. Instead, direct local analysis of the multipliers of interest using the LP method is straightforward.

Let $K$ denote the dimension of the vector of macroeconomic aggregates of interest, $M$ denote the cross-section dimension of countries, and $T$ denote the time dimension of the sample. For any variable $k=1, \ldots, K$ we want to characterize the change of the variable from the start of the recession to some distant horizon $h=1, \ldots, H$, or the change from time $t(p)$ to time $t(p)+h$ where $p$ refers to peak. That is, $t(p)$ denotes the time period that corresponds to the $p^{\text {th }}$ peak or recession. We focus on the change from the start of the recession to some future period so that the results can be directly compared with results available in the literature for unconditional responses.

Let $y_{i t(p)}^{k}$ denote a given macroeconomic aggregate observed for country $i=1, \ldots, M$ at time $t(p)$. The $h$ period ahead change is denoted $\Delta_{h} y_{i t(p)+h}^{k}$. Sometimes $\Delta_{h} y_{i t(p)+h}^{k}$ will refer to the percentage point change, given by the $h$-step difference in 100 times the logarithm of the variable. An example is when $y_{i t}^{k}$ refers to 100 times the logarithm of real GDP per capita. Other times it may refer to the simple $h$-step difference, such as when $y_{i t}^{k}$ refers to an interest rate. These differences are easily understood from the context and we abstain from introducing further notation to indicate the distinction. The macroeconomic aggregates $y_{i t}^{k}$ are consolidated into the vector $Y_{i t}=\left[\begin{array}{llll}\Delta y_{i t}^{1} & \ldots \Delta y_{i t}^{J} y_{i t}^{J+1} \ldots y_{i t}^{K}\end{array}\right]^{\prime}$. The first $J$ elements of this vector refer to variables expressed in first differences, such as 100 times the logarithm of real GDP per capita, and the remaining $K-J$ variables refer to variables in the levels, such as an interest rate.

Lastly, denote $x_{i t(p)}$ the accumulated change of the variable $x$ in the expansion that ended at time $t(p)$ for country $i$. Perturbations of this variable from its longrun mean, e.g., accelerations of borrowing, will define the experiments whose effects on other macroeconomic variables we wish to evaluate. The value of this variable remains fixed for any value of $h$ over which $\Delta_{h} y_{i t(p)+h}^{k}$ is considered.

Consequently, the path of the recession and the recovery, conditional on information up to time $t(p)$-and denoted $Y_{i t(p)}, Y_{i t(p)-1}, \ldots$-will vary depending on $x_{i t(p)}$ and we will be interested in characterizing how these recovery paths 
change as $x_{i t(p)}$ changes from a given baseline level that here we take as the long-run mean, $\bar{x}_{i}$, with respect to an experimental level $\bar{x}_{i}+\delta$.

That is, the average cumulated response for each variable in the $K$-dimensional vector of macroeconomic aggregates is defined as:

$$
\begin{aligned}
& C R\left(\Delta_{h} y_{i t(p)+h}^{k} \delta\right)=E_{i t(p)}\left(\Delta_{h} y_{i t(p)+h}^{k} \mid x_{i t(p)}=\bar{x}_{i}+\delta ; Y_{i t(p)}, Y_{i t(p)-1}, \ldots\right) \\
& -E_{i t(p)}\left(\Delta_{h} y_{i t(p)+h}^{k} \mid x_{i t(p)}=\bar{x}_{i} ; Y_{i t(p)}, Y_{i t(p)-1}, \ldots\right), \quad k=1, \ldots, K ; h=1, \ldots, H .
\end{aligned}
$$

Under the assumption of linearity this cumulated response is simply the sum of the 1 to $h$ impulse responses:

$$
\begin{aligned}
& I R\left(\Delta y_{i t(p)+h^{\prime}}^{k} \delta\right)=E_{i t(p)}\left(\Delta y_{i t(p)+h}^{k} \mid x_{i t(p)}=\bar{x}_{i}+\delta ; Y_{i t(p)}, Y_{i t(p)-1}, \ldots\right) \\
& -E_{i t(p)}\left(\Delta y_{i t(p)+h}^{k} \mid x_{i t(p)}=\bar{x}_{i} ; Y_{i t(p)}, Y_{i t(p)-1}, \ldots\right), \quad k=1, \ldots, K ; h=1, \ldots, H ;
\end{aligned}
$$

that is,

$$
C R\left(\Delta_{h} y_{i t(p)+h^{\prime}}^{k} \delta\right)=\sum_{j=1}^{h} I R\left(\Delta y_{i t(p)+h^{\prime}}^{k} \delta\right) .
$$

Expression (3) can be recognized as the definition of an impulse response in Jordà (2005). The reason to work with expression (2) rather than with expressions (3) and (4) is to provide a direct measure of the cumulated responses that do not rely on the probably implausible assumption of linearity. To proceed we need a way to estimate expression (2).

In practice we estimate $C R\left(\Delta_{h} y_{i t(p)+h^{\prime}}^{k} \delta\right)$ by assuming that the expectation can be approximated by a local projection. In particular, this approximation can be obtained by estimating the following sequence of fixed-effects panel regressions:

$$
\begin{aligned}
\Delta_{h} y_{i t(p)+h}^{k}= & \theta_{N}^{k} d_{i t(p)}^{N}+\theta_{F}^{k} d_{i t(p)}^{F}+\beta_{h, N}^{k} d_{i t(p)}^{N}\left(x_{i t(p)}-\bar{x}_{i}\right)+\beta_{h, F}^{k} d_{i t(p)}^{F}\left(x_{i t(p)}-\bar{x}_{i}\right) \\
& +\sum_{l=0}^{L} \Gamma_{h, l}^{k} Y_{i t(p)-l}+\alpha_{i}^{k}+u_{h, i t(p)}^{k} ; \quad k=1, \ldots, K ; h=1, \ldots, H
\end{aligned}
$$

where $\alpha_{i}^{k}$ are country fixed effects, $u$ is the error term, $\theta_{N}^{k}$ is the common constant associated with normal recessions $d_{i t(p)}^{N}=1$ (o otherwise); $\theta_{F}^{k}$ is the common constant associated with financial crisis recessions $d_{i t(p)}^{F}=1$ (o otherwise); a history of $l$ lags for the control variables $Y_{i t(p)-l}$ with coefficient matrices $\Gamma_{h, l}^{k}$. 
When $x_{i t(p)}=\bar{x}_{i}$ then $\theta_{N}^{k}$ and $\theta_{F}^{k}$ measure the average cumulated response in normal versus financial crisis recessions. Recall that these unconditional means differ in the sample, and allowing for this distinction is consistent with our earlier findings. When $x_{i t(p)}=\bar{x}_{i}+\delta$, the marginal effect of the experiment $\delta$ is given by the coefficients $\beta_{h, N}^{k}$ and $\beta_{h, F}^{k}$ depending on whether the recession is normal $(N)$ or financial $(F)$. Here we could have assumed that $\beta_{h, N}^{k}=\beta_{h, F}^{k}$ but we prefer to omit this restriction, and allow the data to speak out.

Our decision to use a panel estimator with fixed effects allows cross-country variation in the typical path and in the average response to $\delta$. This is a convenient formulation that accounts for variation in the degree of financialization and other macroeconomic differences across countries while still identifying the common component of the response.

If $\delta$ were exogenously determined, then expression (2) would provide the causal effect of an increase $x$ on the outcome $y$ at time $h$. Formally, we cannot claim this to be the case. However, we note that the amount of private credit or public debt is a given quantity at the start of the recession. There is no direct feedback mechanism except for a potential anticipation during the expansion on the severity of an impending recession. We employ regression control on observables $Y$ with set of 8 macroeconomic variables and their lags to soak up variation in economic outcomes that can be explained by conditions experienced during the expansion.

The $Y$ variables that we include as controls are: (1) the growth rate of real GDP per capita; (2) the growth rate of real loans per capita; (3) the consumer price index (CPI) inflation rate; (4) the growth rate of real investment per capita; (5) the growth rate of real public debt per capita; (6) short-term interest rates on government securities (usually 3 months or less in maturity); (7) long-term interest rates on government securities (usually 5 years or more in maturity); and (8) the current account to GDP ratio. Note that our set of controls $Y$ will include data on lending and public debt, which will tend to attenuate any effects that we measure through $x$. That is, we stack the odds against finding that credit or debt have any independent effects on the shape of the recession and recovery.

These variables are the controls included in the vector $Y$ defined earlier. Starting with private credit, we use one times the standard deviation of private credit growth from its long-run average as our "experimental" $x$ variable. In other words, we track how credit booms in the expansion change the conditional forecasts of 
other macroeconomic variables in the subsequent recession and recovery.

Expression (5) serves as the platform from which we develop a more ambitious exploration of the effects of high public debt levels and the interaction between private and public debt overhangs. These extensions will require modifications to our main estimating equation in expression (5) that we discuss as each experiment is introduced below.

\subsection{Private Credit Booms}

We start by determining how strong growth of private credit to GDP in the expansion alters the expected course of an economy through recession and recovery. We look at the effect of a one standard deviation perturbation from the long-run average across all countries in the annual change of private credit in the expansion. This experiment builds on the analysis in Jordà, Schularick and Taylor (2013) but relies on a larger and longer sample. The core results from that study remain largely intact.

Figure 4 4 reports the cumulated responses calculated using expressions (2) and (5) for output, investment, prices, bank lending, and public debt. Price is the CPI level; all other variables are real per capita. Table 3 reports the specific coefficient estimates displayed for the responses of real GDP per capita in the full sample (top row and first column in the figure).

We begin by discussing the responses displayed in Figure 4 4 The top row refers to the full sample analysis whereas the bottom row refers to the post-World War II sample. In a normal recession output declines in year one about 1-2 percent, recovers its original pre-recession level by year two, and then continues to grow in years three to five. However, financial crisis recessions are considerably more painful. On average, they only reach bottom ( -5 percent) around year two or three and output does not quite recover its pre-recession level by year five. If there is overhang from a previous credit boom, the recession can be about two percentage points deeper at the through and the recovery is slower. Real investment, can decline 20-30 percent in crisis recessions. Inflation tends to be more repressed in financial crises and slightly more so after credit booms. Lending activity continues mostly unabated during a normal recession, but it declines in a financial crisis especially after a credit boom. Finally, public debt accelerates faster in financial crisis recessions. All results are quite intuitive and echo recent 
Figure 4: Conditional cumulative change from the start of the recession of selected macroeconomic aggregates as a function of the size of the preceding private credit boom and the type of recession. Samples: 1870-2011 and 1946-2011. Scales matched by column but allowed to vary across variables.
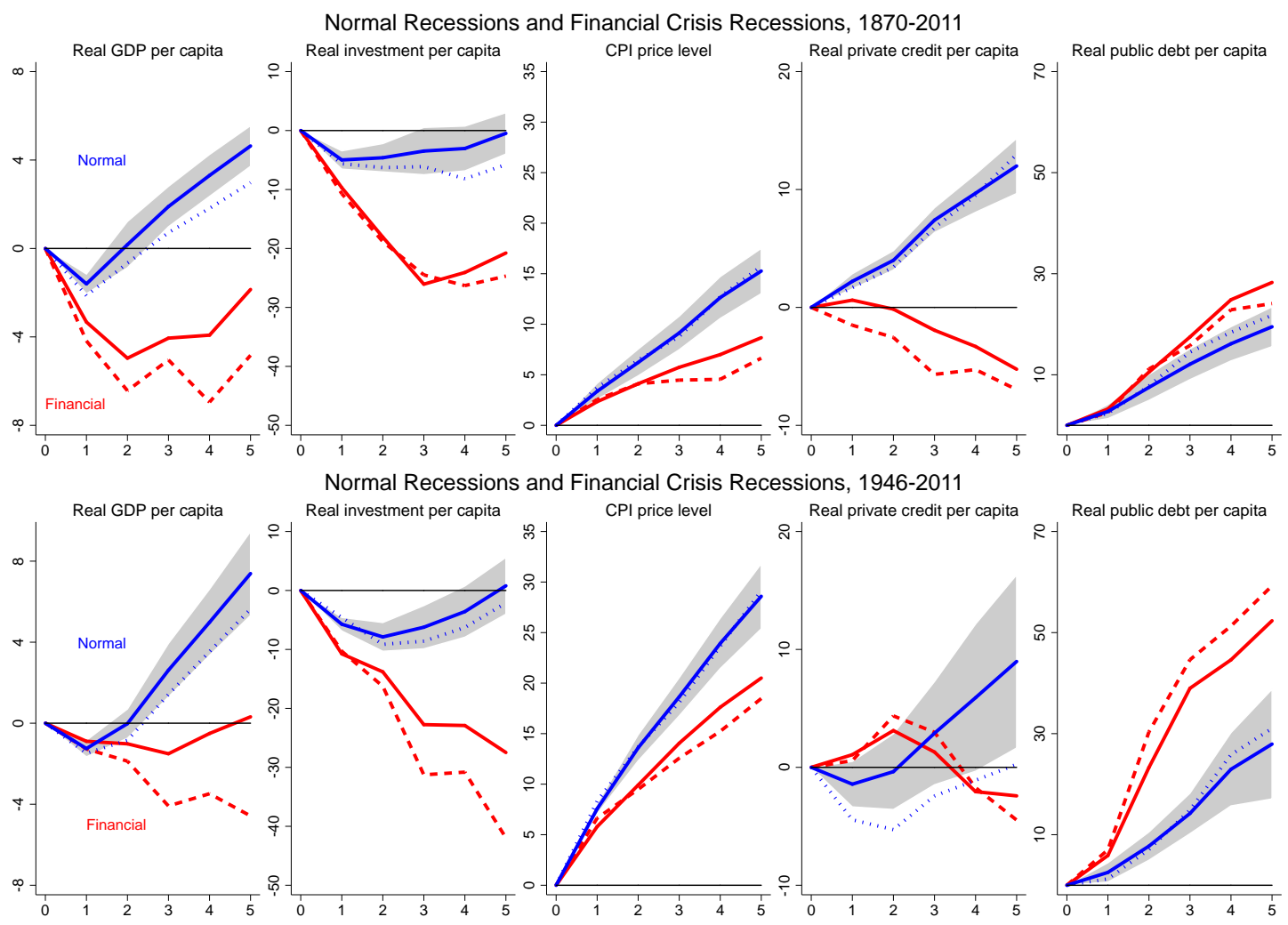

Notes: Each path shows local projections of the cumulative change relative to peak for years $1-5$ of the recession/recovery period under different experiments. Top row refers to an private credit experiment. The solid line with shaded region refers to the average path in normal recessions. The shaded region is a $95 \%$ confidence interval. The dotted line refers to the path in a normal recession when private credit during the expansion grew at the mean plus one standard deviation. The solid line without shaded region refers to the average path in financial crisis recessions. The local projections are conditional on the full set of macroeconomic aggregates and their lags, with paths evaluated at the means. See text.

\section{real-world experiences.}

Table 3 provides more detailed evidence for the full sample responses of real GDP per capita (top row, first column in Figure 4). The table reports local projection coefficient estimates together with robust standard errors (clustered by country) in parentheses. The first two rows capture the average response of output growth in normal and financial crisis recessions. Recall that in the full 
Table 3: Local projections showing response of real GDP per capita, for normal vs. financial crisis recessions, allowing for the size of the preceding private credit boom. Sample: 1870-2011.

Each column shows local projections of the cumulative change in 100 times log real GDP per capita relative to peak for years 1-5 of the recession/recovery period.

\begin{tabular}{lccccc}
\hline \hline & Year 1 & Year 2 & Year 3 & Year 4 & Year 5 \\
\hline Normal recession (average effect) & $-1.60^{* * *}$ & 0.17 & $1.90^{* * *}$ & $3.30^{* * *}$ & $4.64^{* * *}$ \\
& $(0.23)$ & $(0.53)$ & $(0.47)$ & $(0.48)$ & $(0.47)$ \\
Financial recession (average effect) & $-3.33^{* * *}$ & $-4.96^{* * *}$ & $-4.06^{* * *}$ & $-3.92^{* *}$ & -1.85 \\
& $(0.72)$ & $(1.39)$ & $(1.27)$ & $(1.38)$ & $(1.37)$ \\
Private credit, Normal & -0.23 & -0.36 & $-0.50^{*}$ & $-0.64^{* *}$ & $-0.71^{* *}$ \\
& $(0.17)$ & $(0.33)$ & $(0.28)$ & $(0.25)$ & $(0.31)$ \\
Private credit, Financial & -0.34 & -0.59 & -0.39 & -1.21 & -1.19 \\
& $(0.31)$ & $(0.75)$ & $(0.45)$ & $(0.77)$ & $(0.69)$ \\
\hline$R^{2}$ & 0.65 & 0.43 & 0.47 & 0.47 & 0.57 \\
Normal = Financial (average effect), $p$ & 0.08 & 0.02 & 0.00 & 0.00 & 0.00 \\
Normal = Financial (private credit), $p$ & 0.63 & 0.67 & 0.82 & 0.45 & 0.49 \\
Observations & 135 & 135 & 135 & 135 & 135 \\
\hline \hline
\end{tabular}

Notes: ${ }^{* * *} \mathrm{p}<0.01,{ }^{* *} \mathrm{p}<0.05,{ }^{*} \mathrm{p}<0.1$. Robust standard errors (clustered by country) in parentheses. Private credit (followed by either Normal or Financial) refers to the marginal effect of private credit accumulation above the historical mean on the average path in Normal and Financial crisis recessions, respectively. Normal = Financial tests the null that coefficients for each type of recession are the same for the intercept terms in the row labeled average, and for the interaction terms in the row marked Private Credit. In each case the $p$-value of the tests is provided. The local projections are conditional on the full set of macroeconomic aggregates and their lags, with coefficients not reported. See text.

sample 3 out of 4 recessions are of the normal type, and 1 out of 4 is a financial crisis recession. A formal test of the equality of the average responses in normal and financial crisis recessions is provided in the row labeled Normal = Financial (average effect). As the $p$-values show, there is unequivocal statistical evidence that the paths of the recession/recovery differ considerably depending on the type of recession.

The two rows labeled Private credit report the marginal effect of private credit accumulation during the boom on the average path of output growth in the recession/recovery. The row labeled Normal $=$ Financial (private credit) reports the $p$-values of the test that the marginal effect differs by type of recession. Although the effect in financial crisis recessions is about twice as large as the effect in normal recessions and economically important (sometimes nearly one percentage point less real GDP per capita growth per standard deviation), there is insufficient 
evidence in the sample to distinguish the two statistically.

As a robustness check we consider a sub-sample analysis based on post-World War II data, although this sample only contains 11 financial crisis recessions. We have already excluded the two World War periods from the analysis, but the interwar period was unusually turbulent and marked by the Great Depression. The bottom row of Figure 4 replicates the analysis in the top row using the shorter and more contemporary sample from 1946 to 2011.

Broadly speaking, the results hold up qualitatively and quantitatively. Financial crisis recessions are more painful and take longer to recover from than normal recessions although their severity has been somewhat tempered. However, the marginal effect of private credit build up during the boom is not more noticeable. The buildup of public debt is somewhat more rapid, perhaps explaining why financial crisis recessions are somewhat less severe. As a result, the contraction in bank lending is also somewhat less severe.

Overall, the responses confirm that financial crises are more painful and take longer to recover from than normal recessions even after conditioning on macroeconomic aggregates and their lags. Moreover, a large accumulation of private sector debt during the preceding expansion-a private sector credit boomtends to make recessions and recoveries worse.5

\subsection{Public Debt Overhangs}

Using historical data for developed economies starting in the early 1800 , Reinhart and Rogoff (2012) find that the larger the ratio of public debt to GDP is today, the lower output growth will tend to be in the future. In this section we take off from the main premise in Reinhart and Rogoff (2012) and ask if the level of public debt relative to GDP has an effect on the expected path of the economy through recession and recovery.

Put differently, does high public debt make recessions worse and recoveries slower? To estimate these effects, we can modify expression (5) above to measure how the level of debt to GDP modulates the average response in the recession conditional on controls.

Specifically, we now estimate the following sequence of fixed-effects panel

5We ran similar experiments for the accumulation of public debt in the expansion, as opposed to the level which we study in the next section, but did not find strong effects. 
regressions:

$$
\begin{aligned}
\Delta_{h} y_{i t(p)+h}^{k}= & \theta_{N}^{k} d_{i t(p)}^{N}+\theta_{F}^{k} d_{i t(p)}^{F}+\phi_{h, N}^{k} d_{i t(p)}^{N}\left(g_{i t(p)}-\bar{g}_{i}\right)+\phi_{h, F}^{k} d_{i t(p)}^{F}\left(g_{i t(p)}-\bar{g}_{i}\right) \\
& +\sum_{l=0}^{L} \Gamma_{h, l}^{k} Y_{i t(p)-l}+\alpha_{i}^{k}+u_{h, i t(p)}^{k} ; \quad k=1, \ldots, K ; h=1, \ldots, H
\end{aligned}
$$

where $g_{i t(p)}$ denotes the level of debt to GDP for country $i$ at the start to the recession at time $t(p)$.

Using expression (6) we then consider three experiments: the debt level is one standard deviation below the mean, the debt level is at the mean, or the debt level is at one standard deviation above the mean. Recall that from Table 2 that the standard deviation of public debt is about 0.35 (it varies slightly depending on the sample) and the average public debt level is about 0.5 as a fraction of GDP (or 50 percent of GDP). Thus the three experiments refer to situations in which debt is about 15,50, and 85 percent of GDP, what we may call low, medium and high levels of debt relative to GDP (in these experiments, and below, perturbations in public debt are relative to the country mean). We continue to allow the mean to be country-specific to allow for variation in addition to the fixed effect.

The results of these experiments are reported in Figure 5 for normal and financial crisis recessions, using the full sample. Figure 5 displays the trajectory of output, investment, inflation, bank lending and public debt in a normal recession and in a financial crisis recession.

The top row displays typical trajectories in a normal recession. The solid line is the trajectory when the debt level at the start of the recession is at its long-run average (along with a 95\% confidence region); the dotted line when debt is one standard deviation below mean; and the dashed line when debt is one standard deviation above mean. The bottom row maintains the solid line as the trajectory in a normal recession with the debt level at the start of the recession at is long-run average (with a $95 \%$ confidence region) and then adds three additional trajectories, all corresponding to a financial crisis under the three different assumptions on the level of debt. As before, the dotted line corresponds to debt at one standard deviation below the mean; the solid line (without confidence region) refers to debt at the long-run average; and the long-dashed line corresponds to debt at one standard deviation above the long-run average.

Consider the trajectories for output first. Within the confines of our sample 
Figure 5: Conditional cumulative change from the start of the recession of selected macroeconomic aggregates as a function of the public debt level at the start of the recession and the type of recession. Sample: 1870-2011. Scales matched by column but allowed to vary across variables.
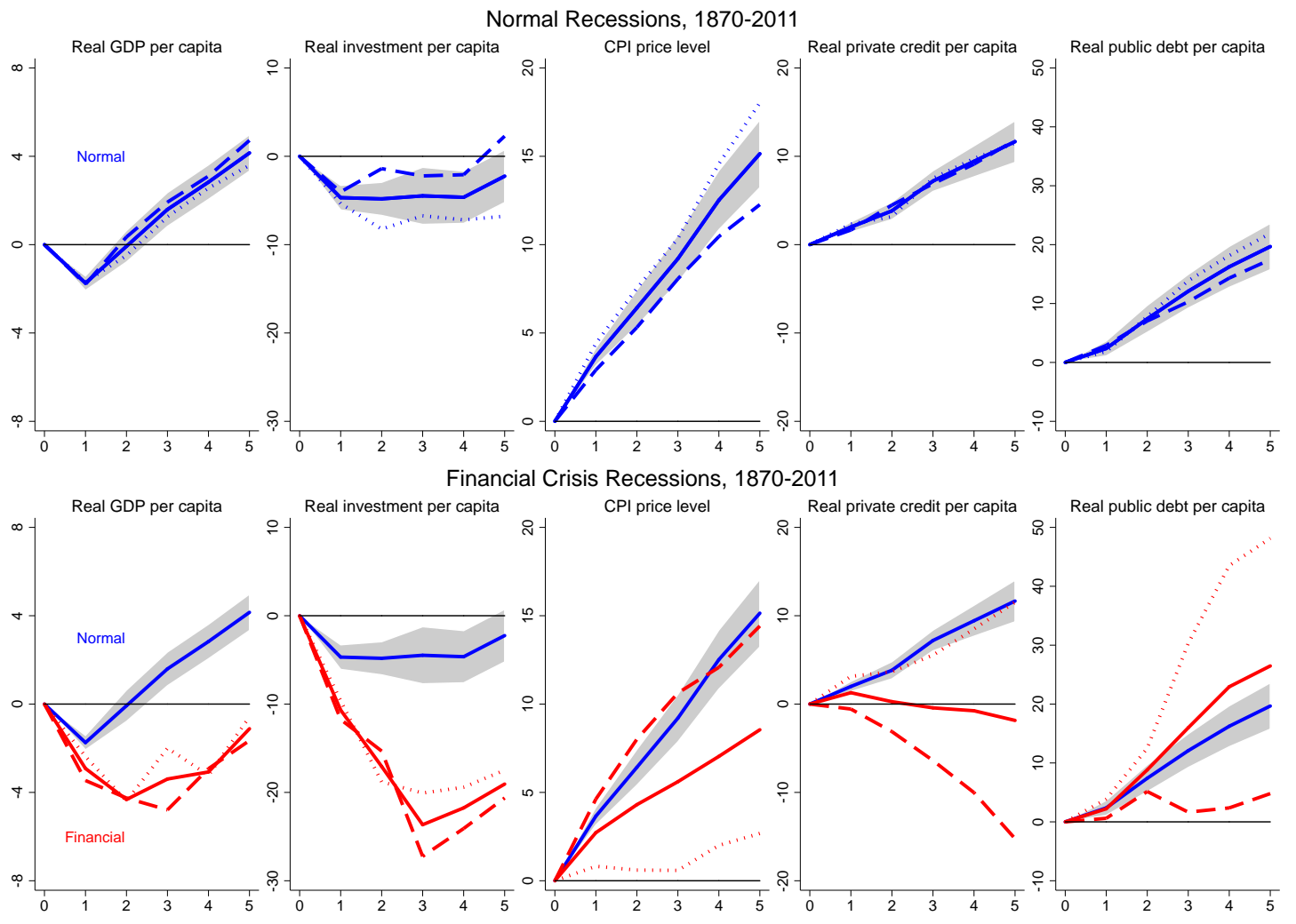

Notes: Each path shows local projections of the cumulative change relative to peak for years $1-5$ of the recession/recovery period under different experiments. Top row refers to normal recessions. Solid line with $95 \%$ confidence region refers to public debt at the historical mean and hence replicates the average response reported in Figure 4 . The dotted line corresponds to public debt one standard deviation below mean, and the dashed line to public debt one standard deviation above the mean. The bottom row refers to financial crisis recessions. The solid line with confidence $95 \%$ region replicates the trajectory displayed in the first row. As with the normal recessions, the dotted line corresponds to public debt one standard deviation below mean, the solid line to public debt at the mean, and the dashed line to public debt one standard deviation above the mean. These results are conditional on the full set of macroeconomic aggregates and their lags, with paths evaluated at the means. See text.

and our methods, the level of public debt at the start of the recession does not meaningfully alter the path of the economy in normal times. The trajectory of output when debt is low, at its long-run mean or high is virtually the same. Much the same is generally true in financial crisis recessions for real GDP per capita, but 
Table 4: Local projections showing response of real GDP per capita, for normal vs. financial crisis recessions, allowing for the public debt level at the start of the recession. Sample: $1870-2011$.

Each column shows local projections of the cumulative change in 100 times log real GDP per capita relative to peak for years $1-5$ of the recession/recovery period.

\begin{tabular}{lccccc}
\hline \hline & Year 1 & Year 2 & Year 3 & Year 4 & Year 5 \\
\hline Normal recession (average effect) & $-1.75^{* * *}$ & -0.07 & $1.59^{* * *}$ & $2.83^{* * *}$ & $4.15^{* * *}$ \\
& $(0.17)$ & $(0.36)$ & $(0.39)$ & $(0.40)$ & $(0.42)$ \\
Financial recession (average effect) & $-2.92^{* * *}$ & $-4.32^{* * *}$ & $-3.39^{* * *}$ & $-3.07^{* *}$ & -1.12 \\
& $(0.53)$ & $(1.03)$ & $(0.98)$ & $(1.12)$ & $(1.15)$ \\
Public debt, Normal & -0.13 & 1.04 & 0.82 & 0.67 & 1.40 \\
& $(0.57)$ & $(0.92)$ & $(1.52)$ & $(2.29)$ & $(2.47)$ \\
Public debt, Financial & -1.43 & 0.18 & -3.67 & 0.39 & -1.41 \\
& $(2.65)$ & $(3.93)$ & $(6.18)$ & $(6.79)$ & $(6.18)$ \\
\hline$R^{2}$ & 0.63 & 0.37 & 0.44 & 0.42 & 0.52 \\
Normal = Financial (average effect), $p$ & 0.10 & 0.01 & 0.00 & 0.00 & 0.00 \\
Normal = Financial (public debt), $p$ & 0.62 & 0.83 & 0.51 & 0.97 & 0.71 \\
Observations & 148 & 148 & 148 & 148 & 148 \\
\hline \hline
\end{tabular}

Notes: ${ }^{* * *} \mathrm{p}<0.01,{ }^{* *} \mathrm{p}<0.05,{ }^{*} \mathrm{p}<0.1$. Robust standard errors (clustered by country) in parentheses. Results correspond to local projections of cumulative change in 100 times log real GDP per capita relative to peak for years $1-5$ of the recession/recovery. Public debt (followed by either Normal or Financial) refers to the marginal effect of the public debt level above the historical mean on the average path in Normal and Financial crisis recessions, respectively. Normal = Financial tests the null that coefficients for each type of recession are the same for the intercept terms in the row labeled average, and for the interaction terms in the row marked Public debt. In each case the $p$-value of the tests is provided. The local projections are conditional on the full set of macroeconomic aggregates and their lags, with coefficients not reported. See text.

the behavior of prices, lending and debt, and somewhat less so investment, display notable differences. The higher the debt level at the start of the recession, the more lending contracts and the more inflation increases. Interestingly, debt grows at the same rate for the first two years regardless of debt levels, but thereafter high levels of debt at the start of the recession result in considerable fiscal retrenchment relative to when debt is low to begin with. Although the decline in lending and debt do not appear to have much of an effect on real GDP per capita, there is a small effect on lending starting in year three that is consistent with this pattern.

Table 4 provides a detailed look at the coefficient estimates behind the responses reported for real GDP per capita in Figure 5. Specifically, the first two rows correspond to the average response of real GDP per capita in Normal and 
Financial crisis recessions and are relative similar in magnitude to the first two rows in Table 3 . The next two rows, labeled Public Debt and either Normal or Financial, contain the marginal effect of public debt on the severity of the recession and are estimated with a great deal of imprecision. As an example, if public debt is running 35 percentage points of GDP (or 1 s.d.) below its long-run country-mean at the recession peak, then the predicted path of the recession (the dotted line in the first row and first column of Figure 5) can be calculated for each year as the sum of the coefficient from the first row in Table 4 minus 0.35 times the coefficient in the third row.

Table 4 contains two formal tests. The line Normal = Financial (average) reports the $p$-values of the per year test of equality that the average trajectory in recessions is the same whether the recession is normal or a financial crisis recession. As in Table 3 this null is easily rejected. Below it, the line Normal = Financial ( $p u b l i c$ ) provides the $p$-values of the test that the marginal effect of the level of public debt at the start of the recession has the same effect whether in normal or financial crisis recessions. These coefficients are imprecisely estimated in the given sample and the null cannot be rejected.

We find evidence that although high levels of public debt do not significantly affect the path of economies out of recessions, there are some interesting differences as to how the recovery occurs. The sample is noisy and we are unable to confirm the results of Reinhart et al. (2012). However, our more granular conditional estimations suggest that the negative effects of high public debt are more visible on other macroeconomic variables. Lending seems to be particularly strongly affected. When debt is low, the recovery from financial crisis recessions seems to be characterized by more aggressive fiscal policy. When debt is high, the opposite happens and there appears to be a considerable amount of fiscal consolidation after two years.

Interestingly, in the context of the current debate it seems that the austerity measures pursued in high debt countries of the euro area are consistent with the historical experience. The question that remains unanswered is whether this result remains when the recession is preceded by a credit boom. We investigate this question in the next section. 


\subsection{Private Credit Booms with Public Debt Overhangs}

So far we have established that private credit booms can be a real drag on the economy but that the same cannot be said of high levels of public debt, at least in times of financial crises. What if both come together? Are the after-effects of private sector credit booms compounded when the public sector is constrained by already high levels of public debt? The goal of this section is to look at the effects of private credit booms and the effects of public debt overhangs discussed in Reinhart et al. (2012) jointly. We will see that, broadly speaking, the interaction matters. Both in normal and financial crisis recessions the drag from a private credit boom is made worse by high levels of public debt.

Looking at private and public debt jointly can be easily accomplished within the statistical design presented in expressions (2), (5) and (6). Specifically, consider extending this last expression as follows:

$$
\begin{gathered}
\Delta_{h} y_{i t(p)+h}^{k}=\theta_{N}^{k} d_{i t(p)}^{N}+\theta_{F}^{k} d_{i t(p)}^{F}+\beta_{h, N}^{k} d_{i t(p)}^{N}\left(x_{i t(p)}-\bar{x}_{i}\right)+\beta_{h, F}^{k} d_{i t(p)}^{F}\left(x_{i t(p)}-\bar{x}_{i}\right) \\
+\phi_{h, N}^{k} d_{i t(p)}^{N}\left(g_{i t(p)}-\bar{g}_{i}\right)+\phi_{h, F}^{k} d_{i t(p)}^{F}\left(g_{i t(p)}-\bar{g}_{i}\right) \\
+\delta_{h, N}^{k} d_{i t(p)}^{N}\left(g_{i t(p)}-\bar{g}_{i}\right)\left(x_{i t(p)}-\bar{x}_{i}\right)+\delta_{h, F}^{k} d_{i t(p)}^{F}\left(g_{i t(p)}-\bar{g}_{i}\right)\left(x_{i t(p)}-\bar{x}_{i}\right) \\
+\sum_{l=0}^{L} \Gamma_{h, l}^{k} Y_{i t(p)-l}+\alpha_{i}^{k}+u_{h, i t(p)}^{k} ; \quad k=1, \ldots, K ; h=1, \ldots, H .
\end{gathered}
$$

The coefficients $\beta_{h, N}^{k}$ and $\beta_{h, F}^{k}$ capture the effect of accumulation of private sector liabilities during the expansion. The coefficients have a similar interpretation to the coefficients in expression (5). Next, the coefficients $\phi_{h, N}^{k}$ and $\phi_{h, F}^{k}$ capture the effect of the level of debt at the start of the recession as discussed in the previous section. Notice that the debt level $g$ enters as deviations from country specific means to allow for cross-country variation. Finally, the coefficients $\delta_{h, N}^{k}$ and $\delta_{h, F}^{k}$ correspond to the interaction of the public debt level with the private credit overhang term. Their purpose is to allow for a modulated effect on $x$. That is, these coefficients allow us to consider whether the effects of a private credit binge during the expansion aggravate a financial crisis recession even more when public debt levels are high to begin with.

Figure 6 displays as concise a summary of the numerous experiments as is possible. The figure is organized in two rows. The top row corresponds to 
Figure 6: Conditional cumulative change from the start of the recession of selected macroeconomic aggregates as a function of the interaction of the size of the preceding private credit boom and the public debt level at the start of the recession and the type of recession. Sample: 1870-2011. Scales matched by column but allowed to vary across variables.
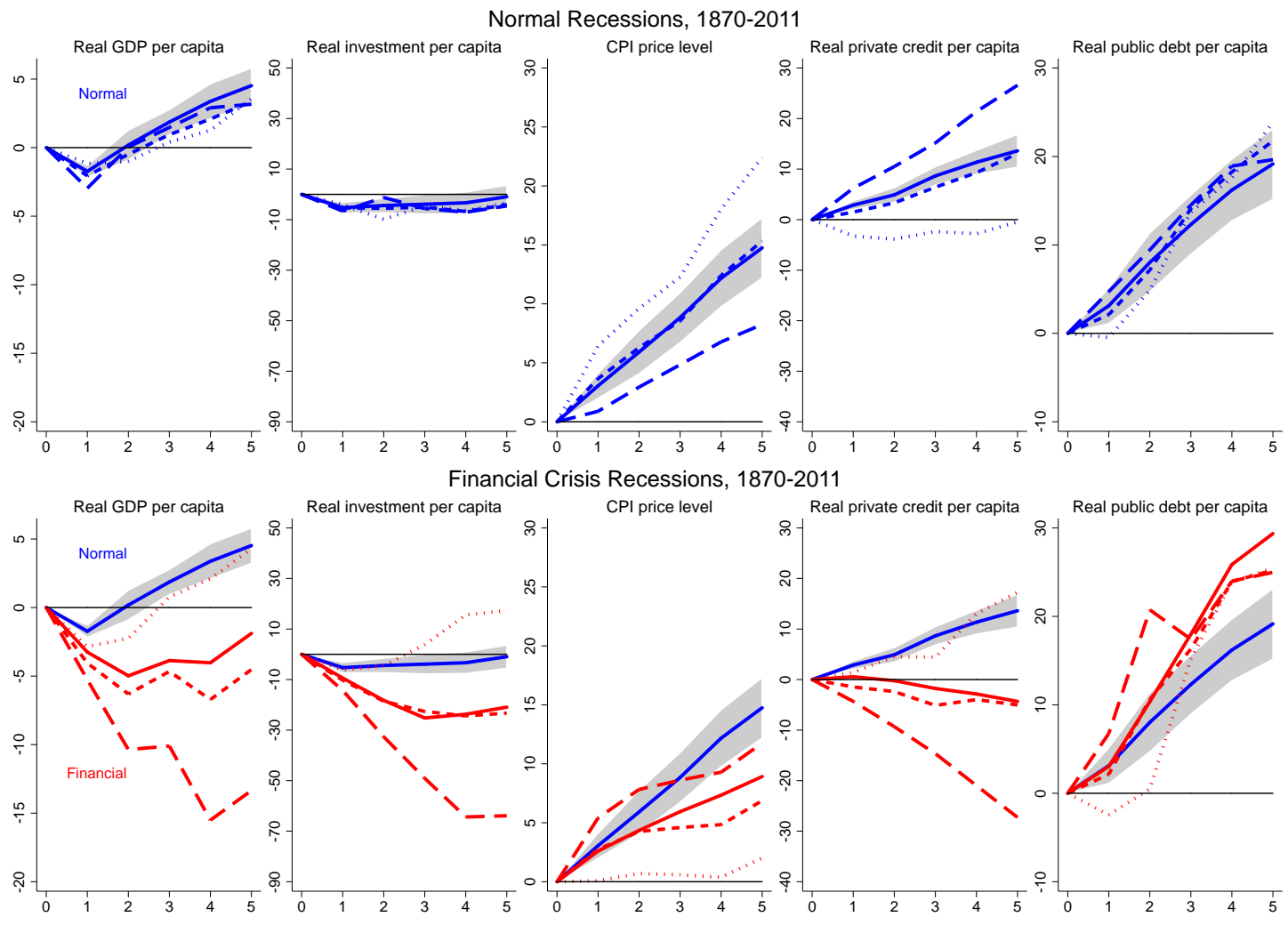

Notes: Each path shows local projections of the cumulative change relative to peak for years $1-5$ of the recession/recovery period under different experiments. Top row refers to normal recessions, bottom row refers to financial crisis recessions. The solid lines depict the average response in each type of recession with all variables at their mean, and in the normal case with a 95 percent confidence region. The various non-solid lines indicate how the path of the economy differs with two simultaneous perturbations: when private credit grows at the average level plus one standard deviation in the previous expansion; and, in addition, when public debt is set one standard deviation below mean, at the mean, or at one standard deviation above the mean. Each of these public debt levels is represented with a dotted line when debt below mean, a short-dashed line when debt is at the mean, and a long-dashed line when debt is above the mean. These results are conditional on the full set of macroeconomic aggregates and their lags, with paths evaluated at the means. See text.

experiments with normal recessions and the bottom row to experiments with financial crisis recessions. Both rows display experiments in which bank lending grew at the average level plus one standard deviation in the previous expansion, but the effect of the private credit overhang is modulated by the level of public 
debt to GDP at the start of the recession. The various dashed lines indicate how the path of the economy differs with public debt one standard deviation below the country mean (about 15 percent of GDP on average), at the long-run country mean (about 50 percent of GDP on average), or one standard deviation above the country mean (about 85 percent of GDP on average). Each of these debt levels is represented with a dotted line when debt is at zero, a short-dashed line when debt is at the mean, and a long-dashed line when debt is at twice the mean. In all figures the average path of normal recessions is displayed as a solid line along with a 95 percent confidence region.

Let's start with the top row. Broadly speaking, these five charts convey a very similar message to the one discovered in the previous section. When the experiment focuses on public debt levels above the historical average there are few differences in real economic outcomes except for the paths of inflation and lending.

However, the real story appears in the second row, in financial crisis recessions. It is clear that high initial levels of public debt to GDP can be a considerable drag on the recovery if they coincide with a substantial private credit overhang. When an above average private sector credit boom is unwound high levels of public debt are problematic. Output stays severely depressed for many years and is far off the previous peak even in year five.

The behavior of investment reinforces this message of a potentially dangerous cocktail of private and public sector debt overhang: after private sector credit booms, high levels of public debt are associated with substantial shortfalls in investment coinciding with prolonged declines in bank lending.

Table 5 provides a granular look at the response of real GDP per capita. The first two rows (labeled Normal recession and Financial recession respectively) contain the coefficients summarizing the average path of each type of recession and correspond rather closely to the coefficients reported in Tables 3 and 4 , The row labeled Normal $=$ Financial (average) again reports the $p$-value of the test of the null hypothesis that the average paths for each type of recession are statistically indistinguishable. That hypothesis is soundly rejected as it was earlier.

The next two rows, labeled Private credit report the coefficients capturing the marginal effect of deviations of bank lending from its mean in normal and financial crisis recessions. Again, these coefficients can be compared directly to the coefficients reported in Table 3 . A test of the null hypothesis that the private credit 
coefficients are equivalent in normal and financial crisis recessions is provided in the row labeled Normal = Financial (credit). Here the null cannot be rejected at conventional significance levels even though the coefficients in financial crisis recessions are between two and three times larger and economically large. By years 4 and 5, and additional one standard deviation above the mean is associated with over two percentage points lower real per capita GDP growth.

The next two rows of coefficients, labeled Public debt, are comparable to the similarly labeled coefficients in Table 4 . Compared to that table, the reported negative effects in financial crisis recessions are larger, more accurately estimated, and economically, quite different to the coefficients in a normal recession. A formal test of equality of the coefficients across type of recession is provided in the row labeled Normal $=$ Financial $(d e b t)$. The null is rejected for year 2 at the $90 \%$ confidence level and year 3 at the $95 \%$ but otherwise, the sample provides insufficient evidence to reject the null. The block of coefficient estimates concludes with two rows of coefficients reporting the interaction terms and labeled Public debt $\times$ private credit. A few of the coefficients are statistically different from zero. However, economically speaking the coefficient estimates suggest that this interaction term captures an important friction for the recovery. A simultaneous deviation of private credit and public debt one standard deviation above the mean can result in about five percent less cumulative growth in real GDP per capita by year five (an average of one percentage point per annum) through this mechanism alone. A test of the null hypothesis that the effect is the same regardless of the type of recession is reported in the row labeled Normal = Financial (interaction). The null is easily rejected in years 2,4 , and 5 , with $p$-values of $0.10,0.02$, and 0.02 , respectively, but not for years 1 and 3 .

The table includes two final formal hypotheses tests. These are designed to evaluate the null that the effect of debt and the effect of the interaction term are simultaneously insignificant. The rows reporting the $p$-values of the test in normal and financial crisis recessions are labeled as Debt (marginal $\mathcal{E}$ interacted). We find some evidence against the null, as in the case of normal recessions, the $p$-value in year 1 is 0.02 , and in financial crisis recessions the $p$-values for years three to five are $0.09,0.09$, and 0.05 respectively. The sample sizes are rather limited and insufficient to provide forceful all around statistical evidence. However, although imprecisely estimated, the economic effects are much too large to be dismissed.

In sum, high levels of public debt can be dangerous and our findings argue in 
Table 5: Local projections showing response of real GDP per capita, for normal vs. financial crisis recessions, allowing for the size of the preceding private credit boom and the public debt level at the start of the recession. Sample: 1870-2011.

Each column shows local projections of the cumulative change in 1oo times log real GDP per capita relative to peak for years $1-5$ of the recession/recovery period.

\begin{tabular}{|c|c|c|c|c|c|}
\hline & Year 1 & Year 2 & Year 3 & Year 4 & Year 5 \\
\hline Normal recession (average effect) & $\begin{array}{c}-1.74^{* * *} \\
(0.22)\end{array}$ & $\begin{array}{c}0.18 \\
(0.55)\end{array}$ & $\begin{array}{c}1.86^{* * *} \\
(0.47)\end{array}$ & $\begin{array}{c}3 \cdot 37^{* * * *} \\
(0.65)\end{array}$ & $\begin{array}{c}4 \cdot 5^{\text {*** }} \\
(0.66)\end{array}$ \\
\hline Financial recession (average effect) & $\begin{array}{c}-3.25^{* * *} \\
(0.71)\end{array}$ & $\begin{array}{c}-4.98^{* * *} \\
(1.43)\end{array}$ & $\begin{array}{c}-3.87^{* * *} \\
(1.21)\end{array}$ & $\begin{array}{c}-4.03^{* * *} \\
(1.37)\end{array}$ & $\begin{array}{l}-1.88 \\
(1.38)\end{array}$ \\
\hline Private credit, Normal & $\begin{array}{l}-0.14 \\
(0.14)\end{array}$ & $\begin{array}{l}-0.28 \\
(0.27)\end{array}$ & $\begin{array}{l}-0.39 \\
(0.25)\end{array}$ & $\begin{array}{l}-0.55^{*} \\
(0.31)\end{array}$ & $\begin{array}{l}-0.50 \\
(0.32)\end{array}$ \\
\hline Private credit, Financial & $\begin{array}{l}-0.32 \\
(0.31)\end{array}$ & $\begin{array}{l}-0.53 \\
(0.70)\end{array}$ & $\begin{array}{l}-0.32 \\
(0.45)\end{array}$ & $\begin{array}{l}-1.07 \\
(0.66)\end{array}$ & $\begin{array}{l}-1.05 \\
(0.66)\end{array}$ \\
\hline Public debt, Normal & $\begin{array}{l}-0.63 \\
(0.81)\end{array}$ & $\begin{array}{c}0.99 \\
(0.82)\end{array}$ & $\begin{array}{c}0.78 \\
(0.92)\end{array}$ & $\begin{array}{c}1.00 \\
(1.47)\end{array}$ & $\begin{array}{c}0.88 \\
(2.06)\end{array}$ \\
\hline Public debt, Financial & $\begin{array}{l}-2.66 \\
(2.81)\end{array}$ & $\begin{array}{l}-4.40 \\
(2.56)\end{array}$ & $\begin{array}{c}-11.34^{* *} \\
(4.83)\end{array}$ & $\begin{array}{l}-7.81 \\
(5.58)\end{array}$ & $\begin{array}{l}-8.79 \\
(5.69)\end{array}$ \\
\hline Pub. debt $\times$ private credit, Normal & $\begin{array}{c}-0.67^{* *} \\
(0.23)\end{array}$ & $\begin{array}{c}0.12 \\
(0.71)\end{array}$ & $\begin{array}{c}0.22 \\
(1.17)\end{array}$ & $\begin{array}{c}0.42 \\
(1.44)\end{array}$ & $\begin{array}{l}-0.58 \\
(1.76)\end{array}$ \\
\hline Pub. debt $\times$ private credit, Financial & $\begin{array}{l}-0.21 \\
(1.41)\end{array}$ & $\begin{array}{l}-2.53 \\
(1.84)\end{array}$ & $\begin{array}{l}-1.22 \\
(2.24)\end{array}$ & $\begin{array}{l}-6.18^{*} \\
(3.12)\end{array}$ & $\begin{array}{c}-5.81^{* *} \\
(2.47)\end{array}$ \\
\hline$R^{2}$ & 0.66 & 0.45 & 0.50 & 0.49 & 0.59 \\
\hline Normal $=$ Financial (average effect),$p$ & 0.12 & 0.02 & 0.00 & 0.00 & 0.00 \\
\hline Normal $=$ Financial (credit),$p$ & 0.49 & 0.68 & 0.88 & 0.51 & 0.42 \\
\hline Normal = Financial (debt) $p$ & 0.46 & 0.06 & 0.02 & 0.16 & 0.16 \\
\hline Normal $=$ Financial (interactions),$p$ & 0.72 & 0.10 & 0.48 & 0.02 & 0.02 \\
\hline Normal, debt effect $=0, p$ & 0.02 & 0.48 & 0.67 & 0.76 & 0.85 \\
\hline Financial, debt effect $=0, p$ & 0.49 & 0.16 & 0.09 & 0.09 & 0.05 \\
\hline Observations & 135 & 135 & 135 & 135 & 135 \\
\hline
\end{tabular}

Notes: ${ }^{* * *} \mathrm{p}<0.01,{ }^{* *} \mathrm{p}<0.05,{ }^{*} \mathrm{p}<0.1$. Robust standard errors (clustered by country) in parentheses. Private credit refers to marginal effect of a credit boom on the path in Normal and Financial crisis recessions. Public debt refers to marginal effect of public debt on the path in Normal and Financial crisis recessions. Interaction credit $\mathcal{E}$ debt refers to the marginal effect of the interaction between a credit boom and public debt in Normal and Financial crisis recessions. Normal = Financial tests the null that the coefficients for the average, credit, debt and interaction cases are the same, reporting the $p$-value of the tests in each case. The lines labeled debt effect $=o$ report the $p$-values of the tests of the null that the coefficients of the marginal effect of public debt and the interaction coefficient are jointly zero in Normal or Financial recessions. The local projections are conditional on the full set of macroeconomic aggregates and their lags (coefficients not reported). See text. 
support of keeping public debt low for precautionary reasons. In particular, high public debt is associated with prolonged spells of weak growth in financial crisis recessions, potentially because the lack of fiscal space undercuts the government's ability to counteract the drag from private sector balance sheet repair.

\section{Conclusion}

This paper provides a first look at over 100 years of the inter-relationships of private credit and sovereign debt. We end with five main conclusions.

First, while public debt has grown in most countries in recent decades, the extraordinary growth of private sector debt (bank loans) is chiefly responsible for the strong increase of total liabilities in Western economies. About two thirds of the increase in total economy debt originated in the private sector. Shadow bank liabilities, important in some cases like the U.S. and U.K. amplify this conclusion. Sovereign and bank debts have generally been inversely correlated over the long run, but have increased jointly since the 1970s. In modern times, the BrettonWoods period stands out as the only period of sustained public debt reduction, both in expansions and recessions.

Second, in advanced economies financial stability risks originate primarily in the private sector rather than in the public sector. To understand the driving forces of financial crises one has to study private borrowing and its problems. In the very long run, if we run a horse race between the impact of changes or run-ups in private credit (bank loans) and sovereign debt as a predictor of financial crisis and its associated distress, private credit is the more significant predictor; sovereign debt adds little predictive information. This fits with the events of 2008 well: with the exception of fiscal malfeasance in Greece most other advanced countries did not have obvious public debt problems ex ante. Of course, ex post, the fierce financial crisis recession would wreak havoc on public finances via crashing revenues and rising cyclical expenditures.

Third, with a broader and longer sample we confirm that private debt overhangs are a regular feature of the modern business cycle. We find that once a country does enter a recession, whether it is an ordinary type or a financial-crisis type of recession, if it carries the legacy of a large private credit boom then the post-recession output path of the economy is typically adversely affected with slower growth. 
Fourth, our new data also allow us to see the distinct contribution of public debt overhangs. We find evidence that high levels of public debt matter for the path of economies out of recessions, confirming the results of Reinhart et al. (2012). But the negative effects of high public debt on the performance of the economy arise specifically after financial crises and in particular when private borrowing also ran high. While high levels of public debt make little difference in normal times, entering a financial crisis recession with an elevated level of public debt exacerbates the effects of private sector deleveraging and typically leads to a prolonged period of sub-par economic performance.

Fifth, from a macroeconomic policy standpoint these findings could inform ongoing efforts to devise better guides to monetary, fiscal, and financial policies going forward, at a time when policymakers are searching for new approaches in the aftermath of the Great Recession. On the private credit side, many countries and international bodies are considering or implementing rules or guides for macro prudential policies that incorporate private credit indicators. On the fiscal side, sovereign stresses in advanced countries have also brought to the fore questions of fiscal space and what limits on average or over the cycle may be usefully employed, whether, for example, in the form of fiscal rules or in better planning the timing of austerity. Our results give some historical underpinnings to these efforts: when private or public debts are elevated the dangers posed by crises and deep recession appear to be amplified.

Three key facts emerge from our analysis of around 150 recessions and recoveries since 1870: first, in a normal recession and recovery real GDP per capita falls by 1.5 percent and takes only 2 years to regain its previous peak, but in a financial crisis recession the drop is typically 5 percent and it takes over 5 years to regain the previous peak; second, the output drop is even worse and recovery even slower when the crisis is preceded by a credit boom; and third, the path of recovery is worse still when a credit-fueled crisis coincides with elevated public debt levels. The current experience in the advanced economies provides a useful out-of-sample comparison, and meshes closely with these historical patterns. 


\section{REFERENCES}

Bordo, Michael D., Barry Eichengreen, Daniela Klingebiel, and María Soledad MartínezPería. 2001. Is the Crisis Problem Growing More Severe? Economic Policy 16(32): $53-83$

Bordo, Michael D., and Joseph G. Haubrich. 2010. Credit Crises, Money, and Contractions: An Historical View. Journal of Monetary Economics 57: 1-18.

Brunnermeier, Markus K., Luis Garicano, Philip R. Lane, Marco Pagano, Ricardo Reis, Tano Santos, Stijn Van Nieuwerburgh, and Dimitri Vayanos. 2011. European Safe Bonds: ESBies. http:/euro-nomics.com/2011/european-safe-bonds/.

Bry, Gerhard, and Charlotte Boschan. 1971. Cyclical Analysis of Time Series: Selected Procedures and Computer Programs. New York: NBER.

Cerra, Valerie, and Sweta C. Saxena. 2008. Growth Dynamics: The Myth of Economic Recovery. American Economic Review 98(1): 439-457.

Checherita, Cristina, and Philipp Rother. 2010. The Impact of High and Growing Government Debt on Economic Growth-An Empirical Investigation for the Euro Area. ECB Working Paper 1237. Forthcoming in European Economic Review.

Claessens, Stijn, M. Ayhan Kose, and Marco E. Terrones. 2011. Financial Cycles: What? How? When? in NBER International Seminar on Macroeconomics 2010 edited by Richard Clarida and Francesco Giavazzi. Chicago: University of Chicago Press, pp. 303-43.

Corsetti, Giancarlo, Keith Kuester, André Meier, and Gernot Müller. 2012. Sovereign Risk, Fiscal Policy, and Macroeconomic Stability. CEPR Discussion Paper 8779.

Eichengreen, Barry, and Kris Mitchener. 2003. The Great Depression is a Credit Boom Gone Wrong. Bank of International Settlements Working Paper 137.

Eggertsson, Gauti B., and Paul Krugman. 2012. Debt, Deleveraging, and the Liquidity Trap: A Fisher-Minsky-Koo Approach. Quarterly Journal of Economics 127 (3): 14691513.

Goldsmith, Raymond W. 1985. Comparative National Balance Sheets: A Study of Twenty Countries, 1688-1978. Chicago: University of Chicago Press.

Guerrieri, Veronica, and Guido Lorenzoni. 2011. Credit Crises, Precautionary Savings, and the Liquidity Trap. NBER Working Paper 17583.

Hall, Robert E. 2011. The Long Slump. American Economic Review 101(2): 431-69.

Howard, Greg, Robert Martin, and Beth Anne Wilson. 2011. Are Recoveries from Banking and Financial Crises Really So Different? Board of Governors of the Federal Reserve System, International Finance Discussion Paper 1037.

Hoffman, Philip T., Gilles Postel-Vinay, and Jean-Laurent Rosenthal. 200o. Priceless Markets: The Political Economy of Credit in Paris: 1660-1870. Chicago: University of Chicago Press.

Ilzetzki, Ethan, Enrique G. Mendoza, and Carlos A. Végh. 2013. How Big (Small?) are Fiscal Multipliers? Journal of Monetary Economics 6o(2): 239-254.

Irons, John, and Josh Bivens. 2010. Government Debt and Economic Growth: Overreaching Claims of Debt "Threshold" Suffer from Theoretical and Empirical Flaws. Economic Policy Institute, Briefing Paper 271. 
Jordà, Òscar. 2005. Estimation and Inference of Impulse Responses by Local Projections. American Economic Review 95(1): 161-182.

Jordà, Òscar, Moritz Schularick, and Alan M. Taylor. 2011. Financial Crises, Credit Booms and External Imbalances: 140 Years of Lessons. IMF Economic Review 59(2): 340-78.

Jordà, Òscar, Moritz Schularick, and Alan M. Taylor. 2013. When Credit Bites Back. Journal of Money, Credit, and Banking 45(s2): 3-28.

Jordà, Òscar, and Alan M. Taylor. 2011. Performance Evaluation of Zero Net-Investment Strategies. NBER Working Paper 17150.

Koo, Richard. 2008. The Holy Grail of Macroeconomics: Lessons from Japan's Great Recession. New York: Wiley.

Kumar, Manmohan S., and Jaejoon Woo. 2010. Public Debt and Growth. IMF Working Paper 10/174.

Laeven, Luc, and Fabian Valencia. 2008. Systemic Banking Crises: A New Database. IMF Working Paper 08/224.

Laeven, Luc, and Fabian Valencia. 2012. Systemic Banking Crises Database: An Update. IMF Working Paper 12/163.

Maddison, Angus. 2005. Measuring and Interpreting World Economic Performance, 1500-2001. The Review of Income and Wealth 51(1): 1-35.

Mian, Atif, Kamalesh Rao, and Amir Sufi. 2013. Household Balance Sheets, Consumption, and the Economic Slump. The Quarterly Journal of Economics 128(4): 1687-1726.

Mian, Atif, and Amir Sufi. 2010. Household Leverage and the Recession of 2007 to 2009. IMF Economic Review 58(1): 74-117.

Minea, Alexandru, and Antoine Parent. 2012. Is High Public Debt Always Harmful to Economic Growth? Reinhart and Rogoff and Some Complex Nonlinearities. Association Française de Cliométrie (AFC) Working Paper 12-08.

Philippon, Thomas, and Virgiliu Midrigan. 2011. Household Leverage and the Recession. NBER Working Paper 16965.

Pozsar, Zoltan, Tobias Adrian, Adam Ashcraft, and Hayley Boesky. 2010. Shadow Banking. Federal Reserve Bank of New York Staff Report 458.

Reinhart, Carmen M., Vincent R. Reinhart, and Kenneth S. Rogoff. 2011. Debt Overhangs: Past and Present. NBER Working Paper 18015.

Reinhart, Carmen M., Vincent R. Reinhart, and Kenneth S. Rogoff. 2012. Public Debt Overhangs: Advanced-Economy Episodes since 1800. Journal of Economic Perspectives 26(3): 69-86.

Reinhart, Carmen M., and Kennth S. Rogoff. 2009a. The Aftermath of Financial Crises. American Economic Review 99(2): 466-72.

Reinhart, Carmen M., and Kenneth S. Rogoff. 2009b. This Time is Different: Eight Centuries of Financial Folly. Princeton, N.J.: Princeton University Press.

Reinhart, Carmen M., and Kenneth S. Rogoff. 2010. Growth in a Time of Debt. NBER Working Paper 15639.

Schularick, Moritz, and Alan M. Taylor. 2012. Credit Booms Gone Bust: Monetary Policy, Leverage Cycles, and Financial Crises, 1870-2008. American Economic Review 102(2): 1029-61.

Tilly, Richard. 2003. Geld und Kredit in der Wirtschaftsgeschichte. Stuttgart: Steiner. 


\section{Appendix 1: Dates of Systemic Financial Crises, 1870-2011}

The crisis prediction classification models in the paper employ data on all systemic financial crises from 1870 to 2011. Dates of systemic financial crises based on Jordà, Schularick, and Taylor (2011) and Schularick and Taylor (2012), sources therein, and updates. See text.

AUS: $1893,1989$.

BEL: 1870, 1885, 1925, 1931, 1939, 2008.

CAN: $1873,1907,1923$.

CHE: 1870, 1910, 1931, 1991, 2008.

DEU: 1873, 1891, 1901, 1907, 1931, 2008.

DNK: 1877, 1885, 1908, 1921, 1987, 2008.

ESP: 1883, 1890, 1913, 1920, 1924, 1931, 1978, 2008.

FIN: 1878, 1900, 1921, 1931, 1991.

FRA: 1882, 1889, 1930, 2008.

GBR: 1873, 1890, 1974, 1984, 1991, 2007.

ITA: 1873, 1887, 1893, 1907, 1921, 1930, 1935, 1990, 2008.

JPN: 1882, 1900, 1904, 1907, 1913, 1927, 1997.

NLD: 1893, 1907, 1921, 1939, 2008.

NOR: 1899, 1922, 1931, 1988.

PRT: 1890, 1920, 1923, 1931, 2008.

SWE: 1878, 1907, 1922, 1931, 1991, 2008.

USA: 1873, 1884, 1893, 1907, 1929, 1984, 2007.

\section{Appendix 2: Dates of Normal and Financial Crisis Recessions, 1870-2006}

The local projections empirical analysis in the paper employs business cycle peaks from 1870 to 2006, excluding windows around the two world wars, with projections out to 5 years ahead, with the annual panel sample data, with the last year's projections from 2006 ending in 2011. As a result, peaks from the 2007-2011 period are not used in the sample, meaning that the empirical work does not include the Global Financial Crisis as an in-sample event. The peak dates which are used are as shown in the table below, where " $\mathrm{N}$ " denotes a normal business cycle peak, and " $\mathrm{F}$ " denotes a peak associated with a systemic financial crisis (a crisis within \pm 2 years of the peak). The dating method follows Jordà, Schularick, and Taylor (2011) and uses the Bry and Boschan (1971) algorithm. See text.

Appendix Table: Dates of Normal and Financial Crisis Recession Peaks

\begin{tabular}{lllllllllllll}
\hline \hline AUS & $\mathrm{N}$ & 1875 & 1878 & 1881 & 1883 & 1885 & 1887 & 1889 & 1896 & 1898 & 1900 & 1904 \\
& & 1910 & 1913 & 1926 & 1938 & 1943 & 1951 & 1956 & 1961 & 1973 & 1976 & 1981 \\
& $\mathrm{~F}$ & 1891 & 1894 & 1989 & & & & & & & & \\
\hline BEL & $\mathrm{N}$ & 1872 & 1874 & 1887 & 1890 & 1900 & 1913 & 1916 & 1942 & 1951 & 1957 & 1974 \\
& & 1980 & 1992 & & & & & & & & & \\
& $\mathrm{~F}$ & 1870 & 1883 & 1926 & 1930 & 1937 & & & & & & \\
\hline \hline
\end{tabular}


Appendix Table (continued)

\begin{tabular}{|c|c|c|c|c|c|c|c|c|c|c|c|c|}
\hline$\overline{\mathrm{CAN}}$ & $\mathrm{N}$ & $\begin{array}{l}1871 \\
1944 \\
1874\end{array}$ & $\begin{array}{l}1877 \\
1947 \\
1907\end{array}$ & $\begin{array}{l}1882 \\
1953\end{array}$ & $\begin{array}{l}1884 \\
1956\end{array}$ & $\begin{array}{l}1888 \\
1981\end{array}$ & $\begin{array}{l}1891 \\
1989\end{array}$ & 1894 & 1903 & 1913 & 1917 & 1928 \\
\hline \multirow[t]{3}{*}{ CHE } & $\mathrm{N}$ & 1875 & 1880 & 1886 & 1890 & 1893 & 1899 & 1902 & 1906 & 1912 & 1916 & 1920 \\
\hline & & 1933 & 1939 & 1947 & 1951 & 1957 & 1974 & 1981 & 1994 & 2001 & & \\
\hline & $\mathrm{F}$ & 1871 & 1929 & 1990 & & & & & & & & \\
\hline \multirow[t]{2}{*}{$\overline{\mathrm{DEU}}$} & $\mathrm{N}$ & 1879 & 1898 & 1905 & 1913 & 1922 & 1943 & 1966 & 1974 & 1980 & 1992 & 2001 \\
\hline & $\mathrm{F}$ & 1875 & 1890 & 1908 & 1928 & & & & & & & \\
\hline \multirow[t]{3}{*}{ DNK } & $\mathrm{N}$ & 1870 & 1880 & 1887 & 1911 & 1914 & 1916 & 1923 & 1939 & 1944 & 1950 & 1962 \\
\hline & & 1973 & 1979 & 1992 & & & & & & & & \\
\hline & $\mathrm{F}$ & 1872 & 1876 & 1883 & 1920 & 1931 & 1987 & & & & & \\
\hline \multirow[t]{3}{*}{ ESP } & $\mathrm{N}$ & 1873 & 1877 & 1892 & 1894 & 1901 & 1909 & 1911 & 1916 & 1927 & 1932 & 1935 \\
\hline & & 1940 & 1944 & 1947 & 1952 & 1958 & 1974 & 1980 & 1992 & & & \\
\hline & $\mathrm{F}$ & 1883 & 1889 & 1913 & 1925 & 1929 & 1978 & & & & & \\
\hline \multirow[t]{3}{*}{$\overline{\text { FIN }}$} & $\mathrm{N}$ & 1870 & 1883 & 1890 & 1898 & 1907 & 1913 & 1916 & 1938 & 1941 & 1943 & 1952 \\
\hline & & 1957 & 1975 & & & & & & & & & \\
\hline & $\mathrm{F}$ & 1876 & 1900 & 1929 & 1989 & & & & & & & \\
\hline \multirow[t]{3}{*}{ FRA } & $\mathrm{N}$ & 1872 & 1874 & 1892 & 1894 & 1896 & 1900 & 1905 & 1907 & 1909 & 1912 & 1916 \\
\hline & & 1920 & 1926 & 1933 & 1937 & 1939 & 1942 & 1974 & 1992 & & & \\
\hline & $\mathrm{F}$ & 1882 & 1929 & & & & & & & & & \\
\hline \multirow[t]{3}{*}{ GBR } & $\mathrm{N}$ & 1871 & 1875 & 1877 & 1883 & 1896 & 1899 & 1902 & 1907 & 1918 & 1925 & 1929 \\
\hline & & 1938 & 1943 & 1951 & 1957 & 1979 & & & & & & \\
\hline & $\mathrm{F}$ & 1873 & 1889 & 1973 & 1990 & & & & & & & \\
\hline \multirow[t]{2}{*}{ ITA } & $\mathrm{N}$ & 1870 & 1883 & 1897 & 1918 & 1923 & 1925 & 1932 & 1939 & 1974 & 2002 & 2004 \\
\hline & $\mathrm{F}$ & 1874 & 1887 & 1891 & 1929 & 1992 & & & & & & \\
\hline \multirow[t]{3}{*}{ JPN } & $\mathrm{N}$ & 1875 & 1877 & 1880 & 1887 & 1890 & 1892 & 1895 & 1898 & 1903 & 1919 & 1921 \\
\hline & & 1929 & 1933 & 1940 & 1973 & 2001 & & & & & & \\
\hline & $\mathrm{F}$ & 1882 & 1901 & 1907 & 1913 & 1925 & 1997 & & & & & \\
\hline \multirow[t]{3}{*}{ NLD } & $\mathrm{N}$ & 1870 & 1873 & 1877 & 1889 & 1894 & 1899 & 1902 & 1913 & 1929 & 1957 & 1974 \\
\hline & & 1980 & 2001 & & & & & & & & & \\
\hline & $\mathrm{F}$ & 1892 & 1906 & 1937 & 1939 & & & & & & & \\
\hline \multirow[t]{2}{*}{ NOR } & $\mathrm{N}$ & 1876 & 1881 & 1885 & 1893 & 1902 & 1916 & 1923 & 1939 & 1941 & 1957 & 1981 \\
\hline & $\mathrm{F}$ & 1897 & 1920 & 1930 & 1987 & & & & & & & \\
\hline \multirow[t]{4}{*}{$\overline{\text { PRT }}$} & $\mathrm{N}$ & 1870 & 1873 & 1877 & 1888 & 1893 & 1900 & 1904 & 1907 & 1912 & 1914 & 1916 \\
\hline & & 1925 & 1927 & 1934 & 1937 & 1939 & 1941 & 1944 & 1947 & 1951 & 1973 & 1982 \\
\hline & & 1992 & 2002 & 2004 & & & & & & & & \\
\hline & $\mathrm{F}$ & 1890 & 1923 & 1929 & & & & & & & & \\
\hline \multirow[t]{3}{*}{ SWE } & $\mathrm{N}$ & 1873 & 1876 & 1881 & 1883 & 1885 & 1888 & 1890 & 1899 & 1901 & 1904 & 1913 \\
\hline & & 1916 & 1924 & 1939 & 1976 & 1980 & & & & & & \\
\hline & $\mathrm{F}$ & 1879 & 1907 & 1920 & 1930 & 1990 & & & & & & \\
\hline \multirow[t]{3}{*}{ USA } & $\mathrm{N}$ & 1875 & 1887 & 1889 & 1895 & 1901 & 1909 & 1913 & 1916 & 1918 & 1926 & 1937 \\
\hline & & 1944 & 1948 & 1953 & 1957 & 1969 & 1973 & 1979 & 1981 & 1990 & 2000 & \\
\hline & $\mathrm{F}$ & 1873 & 1882 & 1892 & 1906 & 1929 & & & & & & \\
\hline
\end{tabular}

